\title{
Systematic satellite observations of the impact of aerosols from passive volcanic degassing on local cloud properties
}

\author{
S. K. Ebmeier ${ }^{1}$, A. M. Sayer ${ }^{2}$, R. G. Grainger ${ }^{3}$, T. A. Mather ${ }^{4}$, and E. Carboni ${ }^{3}$ \\ ${ }^{1}$ COMET, School of Earth Sciences, University of Bristol, Park Street, Bristol, UK \\ ${ }^{2}$ Goddard Earth Science Technology And Research (GESTAR), NASA Goddard Space Flight Center, Greenbelt, MD, USA \\ ${ }^{3}$ COMET, Atmospheric, Oceanic and Planetary Physics, University of Oxford, Parks Road, Oxford, UK \\ ${ }^{4}$ COMET, Department of Earth Sciences, University of Oxford, South Parks Road, Oxford, UK \\ Correspondence to: S. K. Ebmeier (sk.ebmeier@bristol.ac.uk)
}

Received: 22 November 2013 - Published in Atmos. Chem. Phys. Discuss.: 27 January 2014

Revised: 27 August 2014 - Accepted: 8 September 2014 - Published: 9 October 2014

\begin{abstract}
The impact of volcanic emissions, especially from passive degassing and minor explosions, is a source of uncertainty in estimations of aerosol indirect effects. Observations of the impact of volcanic aerosol on clouds contribute to our understanding of both present-day atmospheric properties and of the pre-industrial baseline necessary to assess aerosol radiative forcing. We present systematic measurements over several years at multiple active and inactive volcanic islands in regions of low present-day aerosol burden. The timeaveraged indirect aerosol effects within $200 \mathrm{~km}$ downwind of island volcanoes are observed using Moderate Resolution Imaging Spectroradiometer (MODIS, 2002-2013) and Advanced Along-Track Scanning Radiometer (AATSR, 20022008) data. Retrievals of aerosol and cloud properties at Kîlauea (Hawai'i), Yasur (Vanuatu) and Piton de la Fournaise (la Réunion) are rotated about the volcanic vent to be parallel to wind direction, so that upwind and downwind retrievals can be compared. The emissions from all three volcanoes - including those from passive degassing, Strombolian activity and minor explosions - lead to measurably increased aerosol optical depth downwind of the active vent. Average cloud droplet effective radius is lower downwind of the volcano in all cases, with the peak difference ranging from $2-8 \mu \mathrm{m}$ at the different volcanoes in different seasons. Estimations of the difference in Top of Atmosphere upward Short Wave flux upwind and downwind of the active volcanoes from NASA's Clouds and the Earth's Radiant Energy System (CERES) suggest a downwind elevation of between 10 and $45 \mathrm{Wm}^{-2}$ at distances of $150-400 \mathrm{~km}$ from the volcano, with much greater local $(<80 \mathrm{~km})$ effects. Comparison
\end{abstract}

of these observations with cloud properties at isolated islands without degassing or erupting volcanoes suggests that these patterns are not purely orographic in origin. Our observations of unpolluted, isolated marine settings may capture processes similar to those in the pre-industrial marine atmosphere.

\section{Background}

\subsection{Aerosol indirect effects}

Aerosols affect the Earth's albedo directly, through the absorption and scattering of solar radiation, and indirectly, by altering the properties of clouds. Elevated levels of aerosol potentially lead to higher number densities of cloud condensation nuclei (CCN), and for a parcel of cloudy air with a fixed mass of water, result in higher droplet concentrations and consequently smaller droplets and higher albedo (Twomey or first indirect effect; Twomey, 1977). In addition, smaller cloud droplets may result in the suppression of precipitation and therefore longer cloud lifetime, i.e. higher albedo (second indirect effect, Albrecht, 1989), although the importance of this effect is thought to vary between atmospheric regimes (Stevens and Feingold, 2010). If the overlying air is sufficiently dry, the evaporation of small droplets in a polluted cloud is enhanced, so that cloud water content decreases as droplet concentrations increase (Ackerman et al., 2004). The presence of aerosol in a cloud may also cause the evaporation of cloud droplets due to aerosol absorption of solar radiation, in addition to several less well-understood 
perturbations to droplet character in mixed phase clouds (e.g. Hansen et al., 1997). The impact of secondary aerosol indirect effects has not been well quantified or verified by observations (Rosenfeld et al., 2014).

Aerosol indirect effects (AIE) encompass the combined effects of both anthropogenic and natural emissions. The contributions of AIE to the Earth's radiative balance are strong, yet also highly uncertain. Carslaw et al. (2013) suggest that $45 \%$ of variance in post-1750 aerosol forcing (the contribution of aerosols to the change in the Earth's radiative balance as $\mathrm{CO}_{2}$ levels rise) is from natural sources, which are hard to isolate and measure in the polluted present-day atmosphere (Andreae , 2007). The response of cloud properties to additional $\mathrm{CCN}$ is non-linear: excess $\mathrm{CCN}$ has the greatest effect on albedo when background levels of aerosol are lowest (e.g. Lohmann et al., 2005). Present-day AIE are therefore expected to most closely match pre-industrial processes in remote marine environments where pollution levels are low (Andreae, 2007).

Direct observations of the local effects of aerosols on clouds have so far been dominated by measurements of ship tracks (e.g. Durkee et al., 2000; Ackerman et al., 2000; Campmany et al., 2009; Christensen and Stephens, 2011). Ship tracks provide an ideal experiment for isolating the impact of aerosols, as the polluted clouds are similar in origin and thickness to clean clouds in the surrounding cloud deck, although they may be elevated in height (Christensen and Stephens, 2011). The occurrence and albedo of ship tracks has been shown to depend on pre-existing cloud structure, height and humidity (e.g. Chen et al., 2012). However, Peters et al. (2011) found no statistically significant impact of aerosol from shipping on a large scale, away from the ship tracks themselves.

\subsection{Volcanic aerosol indirect effect}

The impact of volcanogenic aerosol on cloud properties depends on injection height into the atmosphere, pre-existing aerosol burden and synoptic conditions. Explosive eruptions can inject aerosol directly into the stratosphere (as coarse particles from fragmented magma, vent wall erosion and condensation of magmatic gases) and provide the gas-phase reactants for the production of finer aerosols in the plume or ambient atmosphere (e.g. sulfate aerosol). Direct and indirect aerosol effects associated with explosive eruption products in the stratosphere have been relatively well characterised (Sassen, 1992; Robock, 2002; Schmidt et al., 2010). However, the role of aerosol in the troposphere from "passive" degassing and minor eruptions is less well understood (Mather et al., 2003; Oppenheimer et al., 2011). Time-averaged emissions from passive degassing are thought to make up a high proportion $(\sim 30-70 \%)$ of the volcanic $\mathrm{SO}_{2}$ flux to the atmosphere (Andres and Kasgnoc, 1998; Halmer et al., 2002; Mather et al., 2003). Volcanogenic aerosols in the troposphere are expected to be dominated by sulfate aerosol
$\left(\mathrm{SO}_{4}^{2-}\right)$ produced from the oxidation of $\mathrm{SO}_{2}$ by $\mathrm{OH}^{-}, \mathrm{H}_{2} \mathrm{O}_{2}$ or $\mathrm{O}_{3}$ above the boundary layer, or in high-temperature reactions of $\mathrm{SO}_{2}$ or $\mathrm{H}_{2} \mathrm{~S}$ in the volcanic vent (e.g. Mather et al., 2006). Ambient-temperature $\mathrm{SO}_{2}$ reactions can take place over several days, so the impact of volcanic aerosol on number density of CCN may extend hundreds of kilometres away from the aerosol source (Eatough et al., 1995). Volcanic emissions are one source of natural aerosol that, in combination with anthropogenic aerosol, result in AIE. For readability, we refer to this contribution as "volcanic aerosol indirect effects" (VAIE).

The flux of volcanic aerosol to the present-day troposphere is lower than the anthropogenic flux, but its impact on the radiative budget may be disproportionately significant, as volcanic gases are commonly emitted at heights above the boundary layer into the free troposphere so that aerosol lifetimes may be longer (e.g. Graf et al., 1998). In global model simulations of present-day $\mathrm{CCN}$, uncertainties in volcanic aerosol are lower than those for biomass burning and anthropogenic $\mathrm{SO}_{4}^{2-}$ sources (e.g. Lee et al., 2013). However, volcanic emissions contribute a lower proportion of $\mathrm{CCN}$ to the atmosphere today than in pre-industrial times, so the quantification of VAIE are particularly important for estimating the baseline cloud radiative state (Schmidt et al., 2012). Volcanic $\mathrm{SO}_{2}$ emissions have the greatest potential range of all the natural emissions required to estimate global mean forcing uncertainty (Carslaw et al., 2013).

Ground-based measurements of plumes near passively degassing vents have captured (1) an abundance of $\mathrm{SO}_{4}^{2-}$ aerosol larger than the critical diameter to act as a $\mathrm{CCN}$ at typical supersaturations (e.g. Allen et al., 2002; Martin et al., 2008; Mather et al., 2012) and (2) particle growth attributed to the condensation of water vapour onto sulfate particles between 0 and $20 \mathrm{~km}$ distance from the vent (Villarica, Chile; Mather et al., 2004). Satellite remote sensing studies have gone a step further to measuring VAIE during periods of high flux degassing. Gassó (2008) shows alteration to stratocumulus properties ("volcano tracks") in Moderate Resolution Imaging Spectroradiometer (MODIS) and Advanced Microwave Scanning Radiometer - Earth Observing System (AMSR-E) images where large plumes from volcanoes in the South Sandwich islands and the Aleutians interact with marine boundary layer clouds. Instances of increased cloud brightness in the presence of an obvious volcanic plume were identified by browsing MODIS visible images from 6 months in 2006, and cloud property data from a few selected days were analysed to demonstrate first and second AIE in the volcano tracks. Yuan et al. (2011) have also assessed the impact of high degassing flux associated with a new vent opening at Halema'uma'u crater, Hawai'i, in 2008 on trade cumulus clouds. The authors compare retrievals of cloud and aerosol properties averaged over 3 months from inside the Halema'uma'u plume to properties both outside the plume over the same time, and to the average properties retrieved over a much longer period. Both studies (Gassó, 2008; Yuan 
et al., 2011) find evidence for increased albedo and for increased cloud lifetime in marine clouds.

\subsection{Motivation and aim}

Although volcanic aerosol acting as $\mathrm{CCN}$ has been observed at several volcanoes (e.g., Mather et al., 2004; Gassó, 2008; Yuan et al., 2011), its net effect has not previously been quantified over extended periods of time. More representative measurements are important for testing and verifying the predictions of global microphysical aerosol models (e.g. Martin et al., 2006; Dentener et al., 2006; Schmidt et al., 2012) that rely on inventories of sulfur emission such as the one compiled by Andres and Kasgnoc (1998).

As measurements of VAIE so far have been made over short time intervals (3-5 months) and during elevated activity - e.g. frequent MODIS thermal anomalies at Montagu and Saunders Islands (Gassó, 2008) and Halema'uma'u vent opening (Yuan et al., 2011) - they are not likely to be representative of the long-term impact of "background" activity on tropospheric cloud properties.

This study presents an approach for detecting VAIE for the particular case of isolated, active volcanic islands. We use averages of 6-10 years of data and make no selection on the basis of activity, so that our results may be considered representative of the net effect of volcanic emissions on clouds at a particular volcano. Three "control" islands (no volcanic aerosol) are also considered, to provide a comparison with possible island (e.g. orographic) effects on cloud properties. Our aim is to capture the VAIE associated with "background activity" - that is, periods when degassing or other persistent activity results in aerosol emission into the troposphere and that may not result in visibly identifiable "volcano tracks".

\section{Satellite data}

Our analysis uses satellite-retrieved aerosol and cloud properties, specifically aerosol optical depth (AOD) at $550 \mathrm{~nm}$, cloud mid-visible optical depth (COD), and cloud droplet effective radius (CER). Two satellite products are used for each of these quantities. The first is the Collection 6 MODIS Atmospheres Level 2 Joint product (MYDATML2), from the Aqua satellite (data from 2002-2013). These aerosol/cloud data products are described by Platnick et al. (2003), Ackerman et al. (2008) and Levy et al. (2013). MODIS cloud retrievals (resolution $5 \times 5 \mathrm{~km}^{2}$ ) are included where the cloud fraction from MODIS cloud product is >0.2, and Quality Assurance (QA) values are $>0$ (removing data where confidence in the retrieval was low). For aerosol retrievals (resolution $10 \times 10 \mathrm{~km}^{2}$ ), we also require QA $>0$. The second aerosol/cloud data source is the Oxford-RAL Aerosols and Clouds (ORAC) Global Retrieval of Cloud Parameters and Evaluation (GRAPE) data set, from Advanced AlongTrack Scanning Radiometer (AATSR) measurements, from
2002-2008 (Thomas et al., 2009; Sayer et al., 2010, 2011; Poulsen et al., 2012), with data quality-filtered as recommended by the above. Some significant differences in CER between these two data sets were observed by Sayer et al. (2011), attributed in part to the different wavelengths used by the retrieval algorithms, and consequent differences in sensitivity to cloud vertical structure (e.g. Platnick, 2000). For both aerosol data sets, we require pixel cloud fraction $<0.8$. Although there may be artefacts in AOD retrieved in conditions of broken cloud (e.g. Quaas et al., 2010; Grandey et al., 2013), we use AOD retrievals when cloud fraction is up to 0.8 to maximise the number of retrievals in our analysis. Cloud fraction, cloud top pressure and temperature were used to distinguish between retrievals from different atmospheric heights and under different synoptic conditions. We restrict our observations to liquid water rather than ice clouds (and to data where cloud top pressures were $>440 \mathrm{mb}$ ). All properties are resampled to a grid of $10 \mathrm{~km}$ resolution to simplify the comparison. Additionally, data were stratified by season to account for potential large-scale differences in aerosol/cloud properties and data sampling rates in different seasons.

We use Clouds and the Earth's Radiant Energy System (CERES) Single Scanner Footprint data (Top of Atmosphere upward Short Wave flux, resolution $20 \times 20 \mathrm{~km}^{2}$; Geier et al., 2003 ) to estimate radiative impact separately from these microphysical property retrievals. Although differences in solar zenith (expected to be $<10^{\circ}$ in all cases and $<5^{\circ}$ for the majority of retrievals) may result in variations in $\mathrm{SW}$ flux across the region surrounding the volcano, correlations with either cloud properties or wind direction are improbable and are therefore unlikely to affect comparison of upwind and downwind SW fluxes.

Data are selected within a square of side length $4^{\circ}$ (up to $600 \mathrm{~km}$, depending on latitude) centred on the volcanic vent. We then convert the latitude and longitude for each retrieval pixel into polar coordinates with the origin located on the volcano's summit, as recorded in the Smithsonian database (Siebert and Simkin, 2002). Horizontal wind velocity components from the European Centre for MediumRange Weather Forecasts (ECMWF, ERA-Interim, spatial resolution $=1.5^{\circ}$, e.g. Dee et al., 2011) are used to rotate the aerosol and cloud properties according to wind direction, so that they can be plotted according to their expected position upwind or downwind relative to the volcano. ERAInterim horizontal wind velocity components (available five times a day) are selected for the time of day closest to the satellite overflight. We assume that aerosols and their precursor gases are emitted from each volcano at approximately its summit height, so wind data are selected for a pressure level expected to lie just above this height. The volcano's summit or the most active vent is treated as the origin for rotation because for all cases here, gases were emitted from multiple vents contributing varying proportions of total aerosol emissions. 
The resulting averaged images of rotated cloud and aerosol properties allow us to examine systematic trends that are not apparent in the properties retrieved for individual days, or in the average of all our data before rotation. Unlike previous studies at periods of high $\mathrm{SO}_{2}$ emission (e.g. Gassó, 2008; Yuan et al., 2011), volcano tracks were rarely identifiable in individual MODIS visible images or in cloud properties on specific dates. For MODIS and AATSR, retrievals of cloud and aerosol properties are mutually exclusive, as aerosols are retrieved only in clear-sky conditions. CERES Top of Atmosphere (ToA) upward Short Wave (SW) flux is available for both cloudy and clear-sky conditions.

\subsection{Choice of targets}

We select target volcanoes where retrieval uncertainties are expected to be low, to allow us to identify low-magnitude perturbations in cloud properties. Uncertainties in AOD retrieved from MODIS data over land are thought to be on average three times greater than over water, where models of surface reflectance are better (Remer et al., 2005). We therefore focus our study on isolated volcanic islands, avoiding the higher retrieval uncertainties, greater variability in cloud characteristics associated with continents and the systematic dependence of cloud form on wind over coastlines or high topography (e.g. Brenguier et al., 2003). The ideal target is a small and low-lying island volcano, with a high, persistent degassing flux and located a long way from other sources of tropospheric aerosol, such as cities, heavy industry or shipping.

Three isolated, persistently if variably active volcanoes were chosen to test our approach (Figs. 1 and 2): Kīlauea (Hawai'i), Yasur (Vanuatu) and Piton de la Fournaise (Réunion). As described above, measurements of a VAIE downwind of Killauea during the opening of the new Halema'uma'u vent were previously made by Yuan et al. (2011). Although the results presented here are also for mafic, persistently active volcanoes, they capture a range of eruption styles and degassing fluxes (Table 1).

A VAIE is expected to be characterised by (a) elevated AOD and (b) depressed CER downwind of the volcanic source relative to upwind. However, we also expect an orographic effect over isolated peaks in topography (e.g. Jiusto, 1967) to cause a systematic upwind/downwind difference in CER: when moist air is lifted up over an island it expands, cools and condenses, potentially causing precipitation on the windward side of the island. We therefore also consider data for three "control" islands known not to emit volcanogenic aerosol or precursor gases (Tristan da Cunha in the South Atlantic; Ofu-olosega, American Samoa and Fiji, both in the South Pacific - Table 1), chosen for their similarities in height and diameter to our target volcanoes (Fig. 2), and their isolation from other sources of volcanic or anthropogenic aerosol.

\section{Results}

The differences between upwind and downwind aerosol and cloud properties are much greater at the volcanoes than at the control sites. AOD is elevated, CER suppressed and ToA upward SW flux higher downwind of all three volcanoes (Figs. 3-5; Table 2). None of the "control" islands show a notable difference between upwind and downwind properties or a difference in SW flux exceeding $\pm 10 \mathrm{Wm}^{-2}$ (Fig. 5).

Degassing processes and patterns are notably different at each of the volcanoes, and we discuss results from each volcano below with reference to other measurements of volcanic aerosol and prevailing meteorological conditions (Sects. 3.13.3).

\subsection{Kīlauea, Hawai'’}

Killauea is the most active of the Hawaiian volcanoes and contributes $4 \%$ of the total emissions in Andres and Kasgnoc's (1998) time-averaged compilation of emissions from 49 continuously erupting volcanoes. Activity is effusive, and split between the East Rift zone, where lava effusion has been semi-continuous since 1983, and periodic degassing, lava pond activity and occasional small explosions at the volcano's summit. Prior to 2008 approximately $90 \%$ of $\mathrm{SO}_{2}$ emissions were from the East Rift zone, and between 2002 and the beginning of 2008 average total annual emissions were $6.58 \times 10^{5} \mathrm{Mg} \mathrm{yr}^{-1}$ (Elias and Sutton, 2012). A comparison of the USGS ground-based spectrometer measurements with MODIS AOD prior to 2008 for days where both measurements were possible (61 days) does not show a relationship between them (Fig. 6), perhaps due to the time difference between the measurements, the lag between $\mathrm{SO}_{2}$ emission and aerosol formation or processes that affect the concentrations of aerosols, such as dilution.

The opening of a new vent at Halemau'ma'u crater in 2008 was accompanied by a rise in total $\mathrm{SO}_{2}$ flux to $7000 \mathrm{Mg} \mathrm{day}^{-1}$, constituting a doubling of annual $\mathrm{SO}_{2}$ emission rate from 2007 to 2008 . Since 2008 summit emissions steadily increased as a proportion of total $\mathrm{SO}_{2}$ emission from Kîlauea, though total $\mathrm{SO}_{2}$ emission had dropped to $\sim 2000 \mathrm{Mg} \mathrm{day}^{-1}$ by 2010 (Elias and Sutton, 2012). Yuan et al. (2011)'s measurements of the Halema'uma'u 2008 plume demonstrate a significant increase in cloud fraction and perturbation to cloud properties (a) inside the aerosol plume, relative to outside and (b) during elevated emission in 2008, relative to the mean values for the 11-year Terra archive. On 17 July 2008 Yuan et al. (2011) found an average background value of CER of $18 \mu \mathrm{m}$, reduced to $\sim 13 \mu \mathrm{m}$ within the aerosol plume $800-1000 \mathrm{~km}$ downwind of Killauea. We find a similar magnitude of reduction in CER over a much smaller area (just $\sim 70 \mathrm{~km}$ downwind) in averaged MODIS data from 2002-2007, when degassing fluxes were lower, as well as in the multiannual average 2002-2013 (Table 2, Fig. 3). Yuan et al. (2011) found 


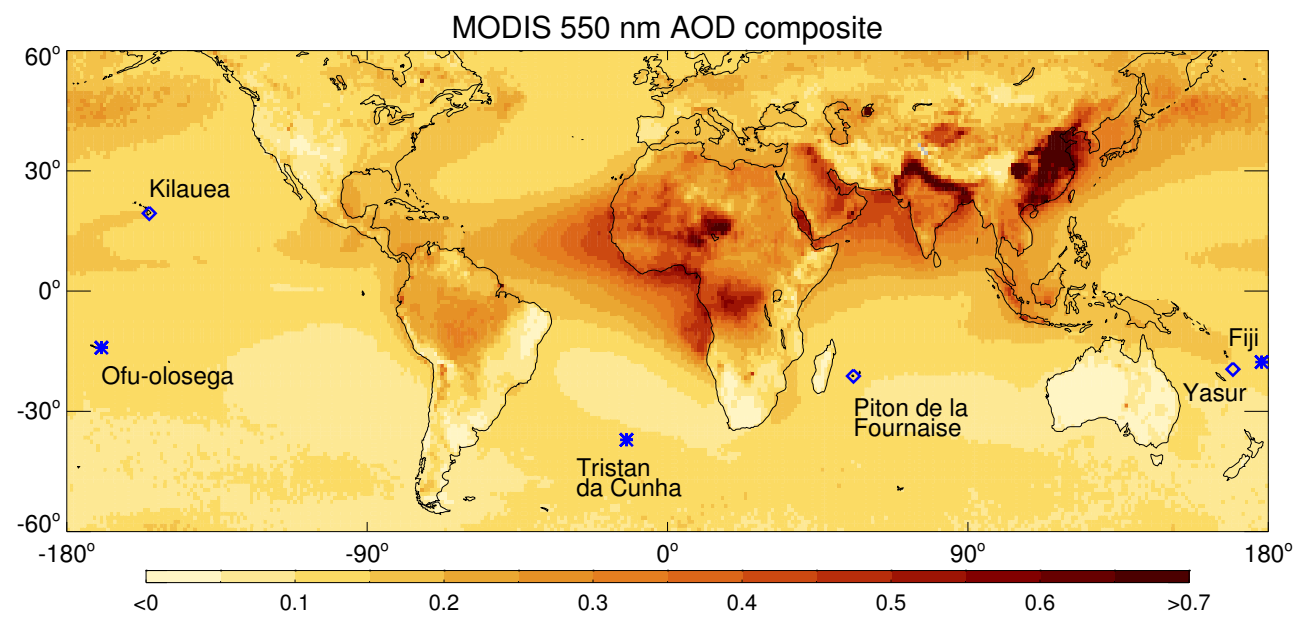

Figure 1. Multiannual mean (2002-2013) of Collection 6 MODIS Aqua AOD at $550 \mathrm{~nm}$ (merged data set). Grey indicates that there are no data. Volcano locations are indicated by blue diamonds, "control" islands by blue crosses.

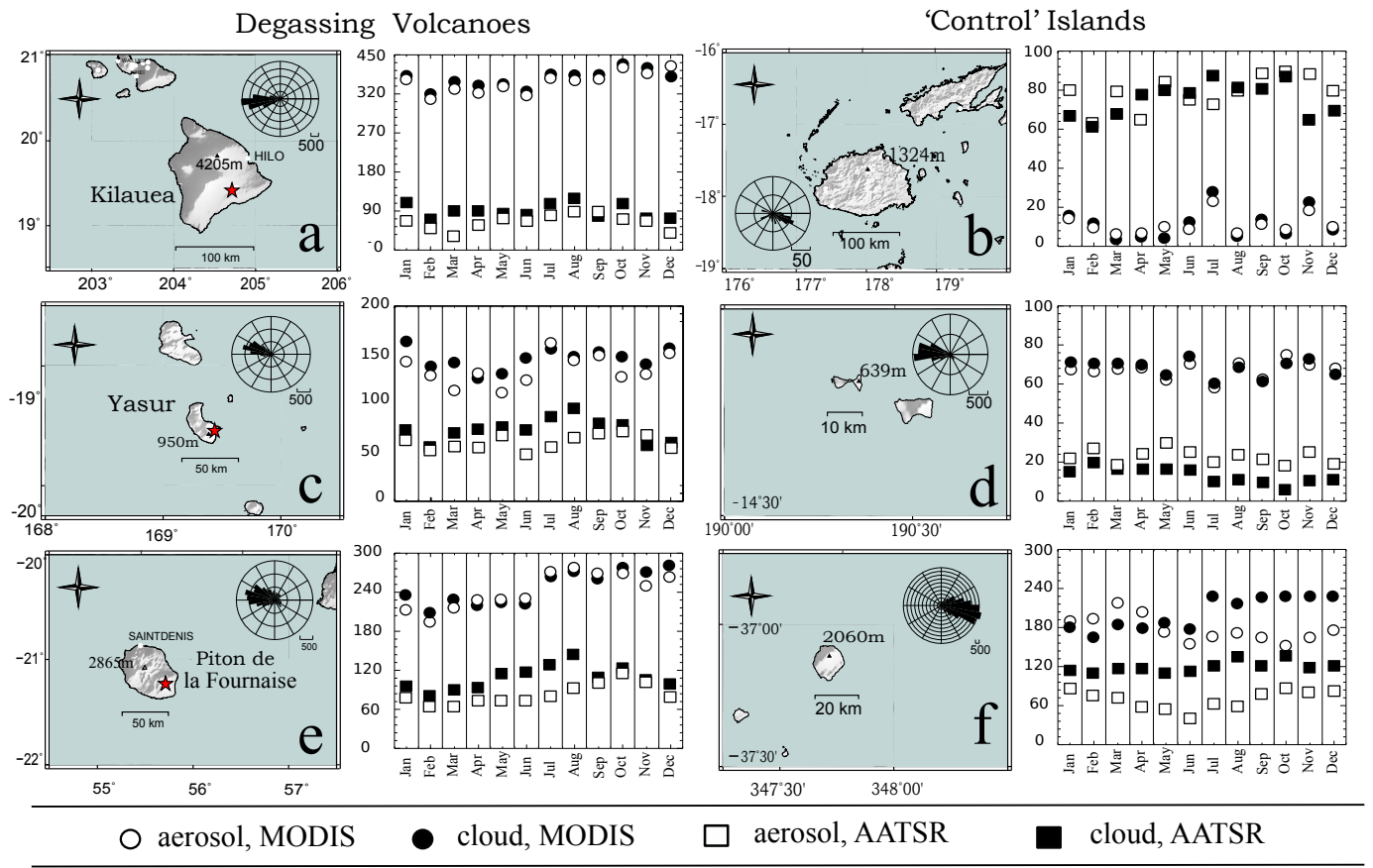

Figure 2. (a-f) Dimensions, topography and seasonal distribution of data sampling for each volcano and control island in the study. Wind roses show daily ECMWF wind directions, black bars indicate the directions towards which the wind was blowing. Locations of degassing vents are marked by red stars. Bar charts show the number of retrievals used in this study for each month of the year, Squares represent number of ENVISAT retrievals, circles, MODIS. Filled shapes are cloud and outlines are aerosol.

a $20 \mathrm{Wm}^{-2}$ perturbation within the 2008 Halema'uma'u plume. At distances of $\sim 150-400 \mathrm{~km}$ downwind of Kîlauea we find perturbations of between 20 and $45 \mathrm{Wm}^{-2}$ (mean $=28 \mathrm{Wm}^{-2}$ ) between 2002 and 2013, well constrained to a region within $\sim 45^{\circ}$ of the downwind direction. Within $\sim 80 \mathrm{~km}$ of the vent, where many retrievals would have been over Hawai' $i$ island itself, the perturbation is even higher, exceeding $90 \mathrm{Wm}^{-2}$ (Fig. 5a-b).
Sulfates dominate the compositions of aerosols measured at Kîlauea's summit (modal diameter $0.44 \mu \mathrm{m}$ ), and make up $\sim 1 \%$ by mass of plume $\mathrm{SO}_{2}$ concentrations (Mather et al., 2012). Porter et al. (2002) made sun photometer and $\mathrm{Li}_{-}$ DAR measurements of $\mathrm{SO}_{4}^{2-} 9 \mathrm{~km}$ downwind of a vent on the East Rift zone in 2001 and found an aerosol dry mass flux rate of $53 \mathrm{Mg}$ day $^{-1}$. They inferred a half-life of 6 hours for $\mathrm{SO}_{2}$ in the plume. Assuming an average wind speed of 
Table 1. Location, physical properties, degassing flux and eruptive character for volcanoes and "control" islands discussed in this study.

\begin{tabular}{|c|c|c|c|c|c|c|}
\hline Volcano/Island & $\begin{array}{r}\text { Latitude } \\
\left({ }^{\circ}\right)\end{array}$ & $\begin{array}{r}\text { Longitude } \\
\left({ }^{\circ}\right)\end{array}$ & $\begin{array}{r}\text { Maximum diameter } \\
\text { of island }(\mathrm{km})\end{array}$ & $\begin{array}{r}\text { Emission (summit) } \\
\text { height }(\mathrm{m})\end{array}$ & $\begin{array}{l}\text { "Background" } \mathrm{SO}_{2} \\
\text { flux* }\left(\mathrm{Mg} \mathrm{day}^{-1}\right)\end{array}$ & Activity $2002-2008$ \\
\hline \multicolumn{7}{|l|}{ Volcanoes } \\
\hline Kîlauea & 19.42 & -155.29 & 130 & $1222(4170)$ & $1800(2002-2007)^{1}$ & Effusive lava flows, lava lake \\
\hline Yasur & -19.53 & 169.44 & 40 & 361 & $633(2004-2008)^{2}$ & Strombolian \\
\hline Piton de la Fournaise & -21.23 & 55.71 & 70 & 2632 & Inter-eruptive flux is very low 3 & Minor explosions and basaltic flows 4 \\
\hline \multicolumn{7}{|l|}{ "Control Islands" } \\
\hline Fiji & -17.63 & 178.02 & 140 & 1324 & - & - \\
\hline Ofu-olosega & -14.18 & 169.62 & 9 & 639 & - & - \\
\hline Tristan da Cunha & -37.09 & -12.28 & 12 & 2060 & - & - \\
\hline
\end{tabular}

* " $\mathrm{SO}_{2}$ flux" refers to time-averaged values of emission not associated with explosions as found from measurements presented by ${ }^{1}$ Elias and Sutton (2012), ${ }^{2}$ Bani et al. (2012)

and ${ }^{3}$ Coppola et al. (2009); Garofalo et al. (2009) and Di Muro et al. (2012).

${ }^{4}$ Periods when eruptions at Piton de la Fournaise occurred: 10.2010-12.2010, 11.2009-01.2010, 09.2008-02.2009, 07.2006-05.2007, 02.2005, 05.2004-10.2004,

05.2003-01.2004 and 11.2002-12.2002; Siebert et al. (2010).

range $5-10 \mathrm{~m} \mathrm{~s}^{-1}$, if correct and broadly applicable in different atmospheric conditions, this implies that $\mathrm{SO}_{2}$ mass falls below $10 \%$ of its original value by a distance of $90-180 \mathrm{~km}$ downwind. Our estimations of average AOD place peak values at $\sim 100 \mathrm{~km}$ downwind of Kîlauea's summit, consistent with oxidation of $\mathrm{SO}_{2}$ as the primary source of aerosol.

Aerosol plume dispersal in Hawai'i is dominated by relatively stable trade winds from the northeast. Clouds are mostly trade cumuli, which are typically capped by the trade wind inversion at a height of a few kilometres. Although Kîlauea's summit elevation is only $1222 \mathrm{~m}$, it overlaps the lower flanks of the much larger, but less active, Mauna Loa $(4170 \mathrm{~m})$. There is a notable difference in the number of MODIS retrievals flagged as cloud downwind relative to upwind (retrievals with cloud fraction $>0.2$ are shown in Fig. 7). More cloud retrievals were made downwind of Killauea, with the difference peaking at a distance of about $60 \mathrm{~km}$ downwind of the vent. Elevated downwind COD is likely to be associated with both the formation of orographic cloud and the action of volcanogenic aerosol as CCN.

\subsection{Yasur, Vanuatu}

Yasur is the southernmost of the Vanuatu island arc's active volcanoes and exhibits almost continuous Strombolian to Vulcanian activity in an eruption that has lasted at least 300 years. Magmatic gases, mostly $\mathrm{SO}_{2}$, are continuously released from three vents in Yasur's crater and typically rise to heights of 700-900 $\mathrm{m}$ before being carried to the northwest by trade winds (Bani et al., 2012). Measurements made by Bani and Lardy (2007) and Bani et al. (2012) on 33 different days between 2004 and 2008 find an average degassing flux of $633 \mathrm{Mg} \mathrm{day}^{-1} \mathrm{SO}_{2}$ (standard deviation of daily measurements $=270 \mathrm{Mg} \mathrm{day}^{-1}$ ). Bani and Lardy (2007) estimate that in 2004-2005 Yasur contributed 1-2\% of estimated global time-averaged volcanic $\mathrm{SO}_{2}$ emissions to the troposphere, close to Andres and Kasgnoc (1998)'s estimation of $3 \%$ pre1990s.
The nearest other aerosol sources to Yasur are just under $400 \mathrm{~km}$ away, at the volcanoes of Lopevi $\left(156 \mathrm{Mg} \mathrm{day}^{-1}\right.$ $\mathrm{SO}_{2}$ ) and Ambrym (5440 Mg day ${ }^{-1} \mathrm{SO}_{2}$ ) (Bani et al., 2012). Yasur is close to being a sea-level point $\mathrm{SO}_{2}$ source, with a summit elevation of just $361 \mathrm{~m}$. We therefore expect any orographic effects to be minimal. There are also no indications of orographic clouds in rotated cloud properties at the small, remote islands in American Samoa (Ofu-olosega, elevation $639 \mathrm{~m}$ ) used as "control" sites.

We measure elevated AOD (e.g. seasonal average upwinddownwind difference of 0.03-0.06 for MODIS (Aqua); 0.020.03 for AATSR) downwind of Yasur, relative to that upwind. Ground-based $\mathrm{SO}_{2}$ measurements at Yasur have been too infrequent (Bani et al., 2012) to allow a useful comparison with AOD retrieved from MODIS data. There is also a net difference in CER between the downwind and upwind sectors (seasonal average differences are $-3--4 \mu \mathrm{m}$, MODIS; $0--4 \mu \mathrm{m}$ AATSR). Although some of this difference can be attributed to the impact of excess aerosol from Yasur, this is superimposed on a regional trend in aerosol and does not clearly indicate statistically significant AIE. Similarly, the elevation in ToA upward SW flux downwind of Yasur (Fig. 5c-d) is likely to be influenced by regional variation in cloud properties, rather than purely volcanic effects.

\subsection{Piton de la Fournaise, Réunion}

Piton de la Fournaise, Réunion, differs from the previous two examples in that intra-eruptive $\mathrm{SO}_{2}$ flux is low (Khokhar et al., 2005; Di Muro et al., 2012). However, Piton de la Fournaise is very active, on average it erupts or experiences an intrusion once every 8 months (Peltier et al., 2009). Eruptions are sometimes associated with measurable $\mathrm{SO}_{2}$ emission (Khokhar et al., 2005; Bhugwant et al., 2009), and emission is of longer duration during periods of distal lava effusion when lava entering the sea also results in a high flux of water vapour to the atmosphere (e.g. Gouhier and Coppola, 2011). Between eruptions, degassing is primarily from low temperature fumeroles and fractures around the active 

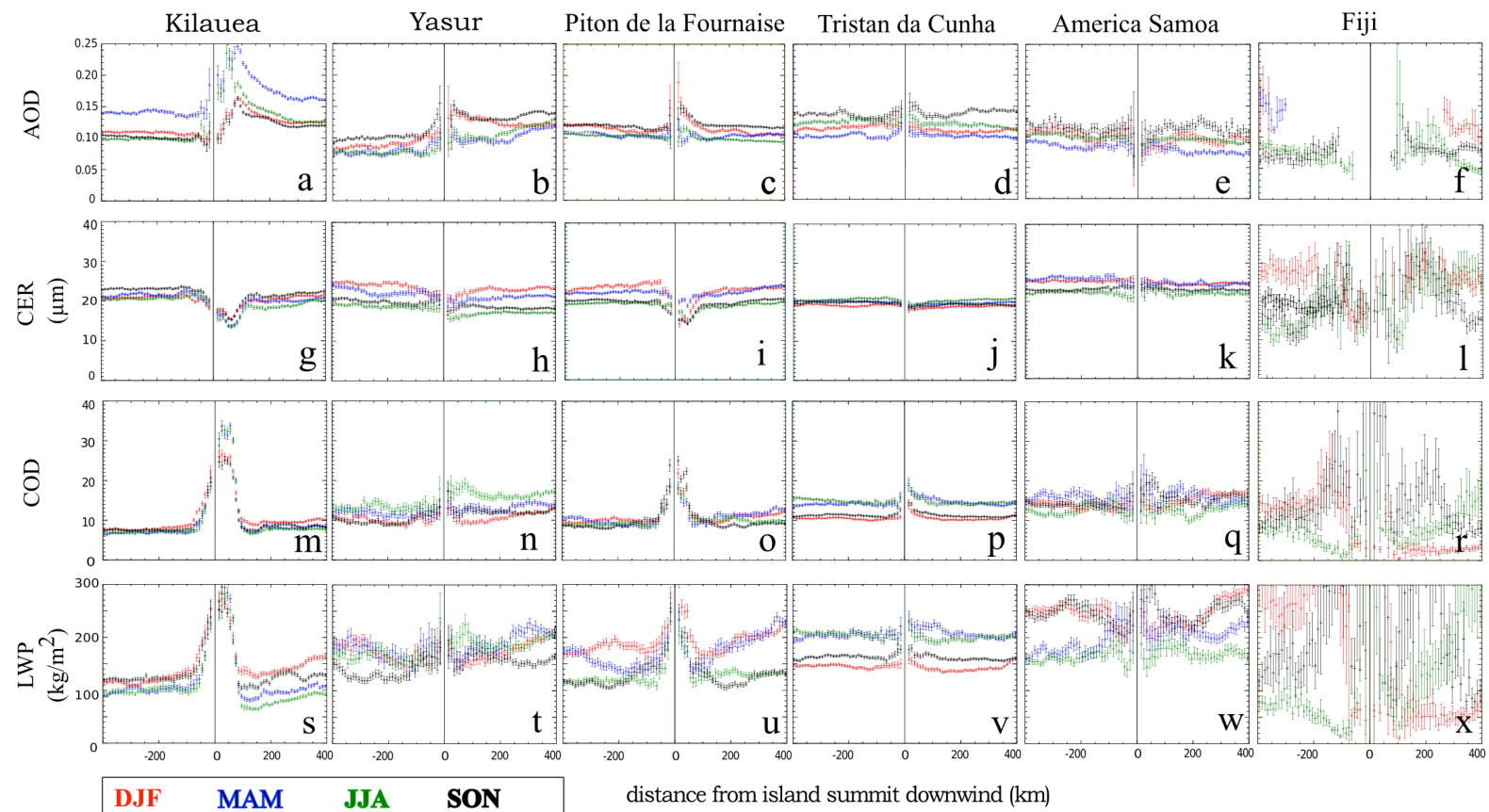

Figure 3. Profiles of average aerosol and cloud properties upwind and downwind of the degassing volcano: Kîlauea, Hawai'i; Yasur, Vanuatu and Piton de la Fournaise, Réunion and at "control" islands: Tristan da Cunha, South Atlantic; American Samoa, West Pacific and Fiji, West Pacific. Profile values are the average of $\operatorname{arcs}$ of $\frac{\pi}{2}$ at equal distance upwind and downwind from the volcano vent for MODIS Aqua data from between 2002 and 2013. Separate profiles for different time of year are shown in different colours: December-February in red, March-May in blue, June-August in green and September-November in black. Error bars show one standard error for this average and are generally larger for low sample sizes. Positive values on the $x$-axis are downwind, negative are upwind. The maximum diameter of the islands is indicated on the parameter plots as black dashed lines.
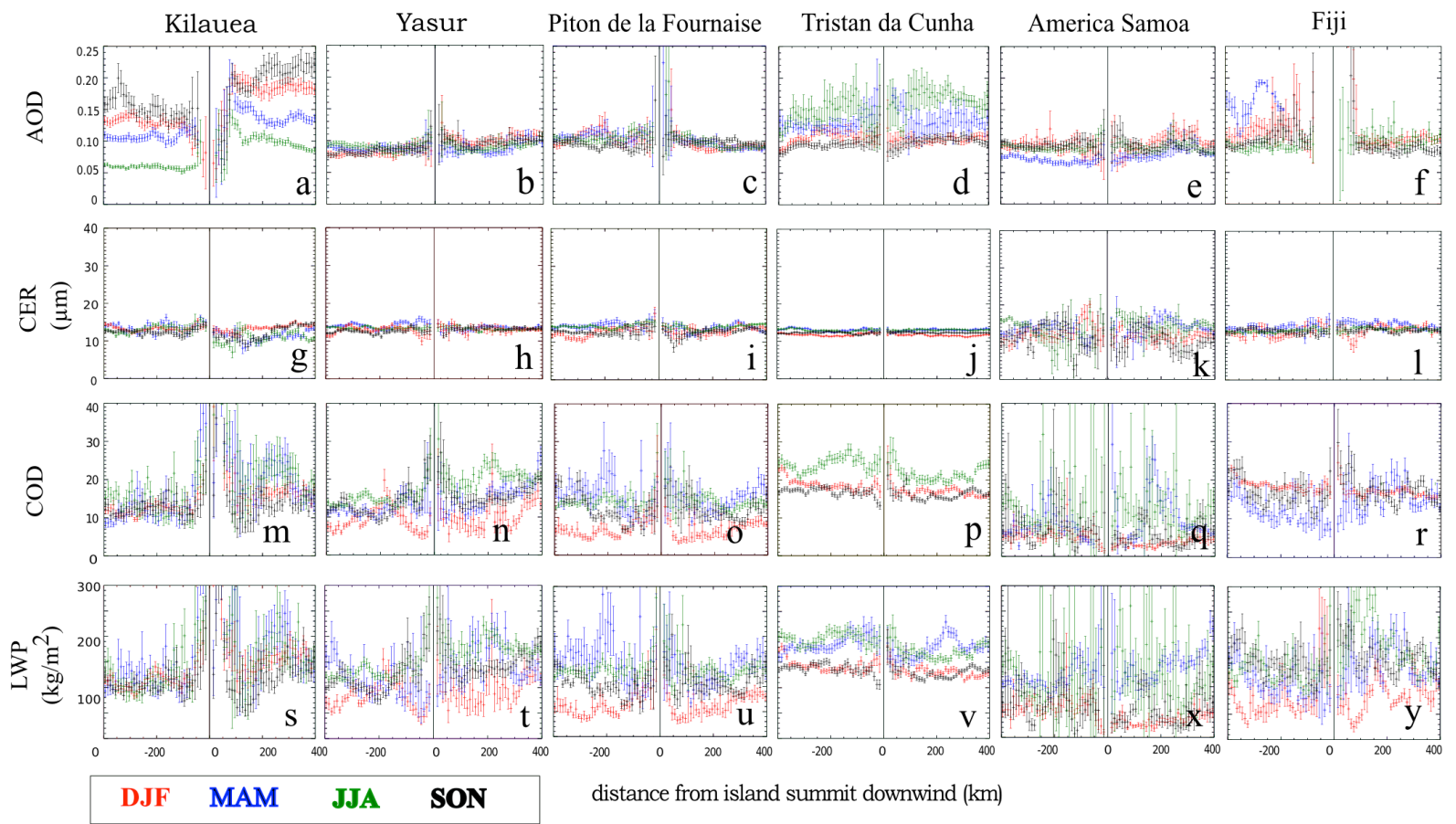

Figure 4. Profiles of average aerosol and cloud properties from AATSR between 2002 and 2008, upwind and downwind of the degassing volcano, presented as in Fig. 3, above. 
summit crater (Di Muro et al., 2012). Again, unlike Kîlauea and Yasur, these weak emissions are dominated by water vapour, and hydrogen sulfide $\left(\mathrm{H}_{2} \mathrm{~S}\right)$ is the main sulfur species (Di Muro et al., 2012). La Réunion is located near an important shipping lane (Peters et al., 2011), so it is possible that some anthropogenic sources of sulfate aerosol may also be present.

Piton de la Fournaise is the only one of the volcanoes investigated here that is likely to have had a high $\mathrm{SO}_{2}$ flux associated with explosive eruption. The $\mathrm{SO}_{2}$ released during the collapse of the Dolomieu crater in April 2007 (estimated to be $935 \pm 244$ kilotons by Gouhier and Coppola, 2011) rose quickly to heights $>3000 \mathrm{~m}$ (above the trade winds), and reached distances of $800-1000 \mathrm{~km}$ away from La Réunion within days (Tulet and Villeneuve, 2011). Where $\mathrm{SO}_{2}$ emission accompanies explosions, and aerosol is carried above the trade winds, the aerosol and associated impact will be spread over a much greater area. At distances of $\sim 1000 \mathrm{~km}$, the plume from this event reached heights of around $10000 \mathrm{~m}$ above sea level (Tulet and Villeneuve, 2011), so aerosol from the plume are only likely to settle out and re-enter the lower atmosphere at great distance from the volcano. Piton de la Fournaise's other six eruptions between 2002 and 2008 (Siebert et al., 2010) were all less explosive, emitting aerosol lower into the atmosphere.

Differences between upwind and peak downwind AOD at Piton de la Fournaise range from 0.01 to 0.08 (MODIS) in different seasons at $\sim 50 \mathrm{~km}$ distance from the volcano's summit, while differences in CER are $-2--10 \mu \mathrm{m}$ (seasonal and multiannual mean MODIS and AATSR values shown in Figs. 3, 4 and 8.) Peak downwind elevation in ToA upward $\mathrm{SW}$ flux is $\sim 28 \mathrm{Wm}^{-2}$ at $20 \mathrm{~km}$ downwind of the volcano (Fig. 5e-f).

Our observations capture the impact primarily of lowaltitude aerosol emission. However, our observations of VAIE are not limited to inter-eruptive emission. In Fig. 9 aerosol and cloud properties are split according to whether or not Piton de la Fournaise was erupting (as recorded in the Smithsonian database; Siebert and Simkin, 2002). Aerosol is elevated all around the volcano during periods of eruption (compare Fig. 9a and b), but particularly in the downwind quadrant. Similarly, CER is lowest during periods of eruption in the downwind sector (compare Figs. $9 \mathrm{c}$ and d).

\subsection{Distinguishing between orographic and volcanic effects}

Orographic clouds form when moist air is forced upwards by high topography so that it expands and cools below its saturation point. Their form depends on relative humidity, wind speed and the height and geometry of topography. At high humidity and lower wind speeds, droplets condense above the windward slopes of a mountain, sometimes causing orographic precipitation. Wave clouds may also form in perpendicular bands downwind of high topography. At isolated, steep-sided mountains high wind speeds can cause local uplifting on the upper slopes in the lee side of the mountain ("banner cloud"). As the formation of orographic cloud is controlled by wind strength and direction, its presence is expected to introduce systematic features to our rotated cloud properties.

For a tall, isolated island, orographic clouds may form (1) over high land upwind of the summit and (2) at the crests of lee waves (rotor and lenticular clouds), downwind and extending hundreds of kilometres away from the island (e.g. Houze, 1994). We observe elevated COD in averaged cloud property data over the islands with high topography (Kîlauea, Réunion, Fiji and to some extent Tristan da Cunha). COD is elevated immediately upwind of the islands' summit and remains high over land downwind. Any difference in COD between the windward and lee sides of the islands at greater distance is very low, suggesting that the contribution of wave clouds to the average values is small.

This is confirmed by estimating the average cloud properties for days with different tropospheric stabilities (Fig. 10). Tropospheric stability was approximated by the unsaturated moist Froude number estimated from ECMWF reanalysis data: $F r^{2}=\frac{u^{2}}{N^{2} h^{2}}$, where $u$ is wind speed at the height $(h)$ of the island and $N$ is the unsaturated moist Brunt-Väisälä frequency. $N$ is also estimated from ECMWF temperatures at atmospheric pressures $>750 \mathrm{mb}\left(N^{2}=\frac{g}{\theta_{v}} \frac{\delta \theta_{v}}{\delta z}\right.$, where $g=$ gravitational acceleration, $\theta_{v}=$ virtual potential temperature and $z=$ atmospheric thickness). Where Froude number is low $(<0.1$, blue on Fig. 10) air will flow around a mountain, rather than over it. For Froude numbers closer to $1(0.1-0.5$, green and $>0.5$ red on Fig. 10), lee waves and wave clouds will form. At higher Froude numbers air flows over the island very fast and there are no stable layers. Although COD is higher at greater Froude number at Yasur and Piton de la Fournaise (Fig. 10), atmospheric stability seems to have a limited effect on systematic differences between CER upwind and downwind.

Orographic cloud has smaller droplets at a higher density than marine clouds. For example, Jiusto's (1967) aircraft sampling of both marine and orographic cloud upwind of Killauea found that marine clouds had an average radius of $22 \pm 3 \mu \mathrm{m}$ (droplet concentration $45 \pm 22 \mathrm{~cm}^{-3}$ ) while clouds on the flanks of Mauna Loa had an average radius of $14 \pm 3 \mu \mathrm{m}$ (droplet concentration $100 \pm 50 \mathrm{~cm}^{-3}$ ). Although the values are not directly comparable, we find a similar decrease in droplet size (seasonal averages $-2--8 \mu \mathrm{m}$, see Table 2) on the windward side of Big Island Hawai' $i$. However, CER does not reach its minimum value until almost $100 \mathrm{~km}$ downwind, and remains lower than upwind values until almost $400 \mathrm{~km}$ from land (see Fig. 3). We see no such effect in clouds downwind of Fiji (also $\sim 100 \mathrm{~km}$ across and in the path of easterly trade winds, but lower in elevation) or American Samoa, but Tristan da Cunha shows a small decrease in droplet size in data from December-February. We note that 
Table 2. Average difference in upwind and downwind cloud and aerosol properties for MODIS (Aqua) and AATSR retrievals for volcanoes discussed in this study. Uncertainties are the square root of the sum of squares of the standard errors of upwind and downwind values.

\begin{tabular}{|c|c|c|c|c|c|c|}
\hline Volcano & & & $\Delta \mathrm{AOD}^{1}$ & $\Delta \mathrm{COD}^{2}$ & $\Delta \mathrm{CER}(\mu \mathrm{m})^{1}$ & Peak distance $(\mathrm{km})^{3}$ \\
\hline \multirow[t]{8}{*}{ Piton de la Fournaise } & MODIS & DJF & $0.08 \pm 0.03$ & $2 \pm 1$ & $-8 \pm 1$ & $\sim 25$ \\
\hline & & MAM & $0.03 \pm 0.03$ & $3 \pm 1$ & $-3 \pm 1$ & $\sim 30$ \\
\hline & & JJA & $0.03 \pm 0.02$ & $2 \pm 1$ & $-3 \pm 1$ & $\sim 50$ \\
\hline & & SON & $0.04 \pm 0.02$ & $<1$ & $-4 \pm 1$ & $\sim 40$ \\
\hline & AATSR & DJF & $0.02 \pm 0.02$ & $<1$ & $-4 \pm 2$ & $\sim 40$ \\
\hline & & MAM & $0.03 \pm 0.02$ & $-2 \pm 4$ & $-3 \pm 2$ & $\sim 15$ \\
\hline & & JJA & $0.03 \pm 0.02$ & $<1$ & $-2 \pm 2$ & $\sim 25$ \\
\hline & & SON & $0.01 \pm 0.02$ & $<1$ & $-4 \pm 2$ & - \\
\hline \multirow[t]{8}{*}{ Yasur } & MODIS & DJF & $0.06 \pm 0.01$ & $<1$ & $-4 \pm 1$ & $\sim 40$ \\
\hline & & MAM & $0.03 \pm 0.01$ & $2 \pm 2$ & $-3 \pm 1$ & $\sim 25$ \\
\hline & & JJA & $0.04 \pm 0.01$ & $5 \pm 2$ & $-4 \pm 1$ & $\sim 35$ \\
\hline & & SON & $0.05 \pm 0.01$ & $3 \pm 2$ & $-3 \pm 1$ & $\sim 40$ \\
\hline & AATSR & DJF & $0.03 \pm 0.02$ & $<1$ & $<1$ & - \\
\hline & & MAM & $0.02 \pm 0.02$ & $2 \pm 3$ & $-4 \pm 2$ & $\sim 40$ \\
\hline & & JJA & $0.02 \pm 0.02$ & $5 \pm 3$ & $<1$ & - \\
\hline & & SON & $0.03 \pm 0.02$ & $2 \pm 3$ & $-2 \pm 2$ & $\sim 40$ \\
\hline \multirow[t]{8}{*}{ Kîlauea } & MODIS & DJF & $0.06 \pm 0.01$ & $2 \pm 1$ & $-6 \pm 1$ & $\sim 90$ \\
\hline & & MAM & $0.11 \pm 0.02$ & $4 \pm 1$ & $-6 \pm 1$ & $\sim 100$ \\
\hline & & JJA & $0.14 \pm 0.02$ & $4 \pm 1$ & $-8 \pm 1$ & $\sim 70$ \\
\hline & & SON & $0.05 \pm 0.02$ & $2 \pm 1$ & $-8 \pm 1$ & $\sim 90$ \\
\hline & AATSR & DJF & $0.07 \pm 0.03$ & $4 \pm 2$ & $-2 \pm 1$ & $\sim 100$ \\
\hline & & MAM & $0.08 \pm 0.03$ & $5 \pm 3$ & $-4 \pm 3$ & $\sim 90$ \\
\hline & & JJA & $0.08 \pm 0.02$ & $5 \pm 3$ & $-5 \pm 3$ & $\sim 90$ \\
\hline & & SON & $0.06 \pm 0.03$ & $2 \pm 2$ & $-2 \pm 2$ & $\sim 90$ \\
\hline \multirow[t]{8}{*}{ Tristan } & MODIS & DJF & $-0.02 \pm 0.02$ & $2 \pm 1$ & $-2 \pm 1$ & $\sim 20$ \\
\hline & & MAM & $0.01 \pm 0.02$ & $3 \pm 1$ & $-1 \pm 1$ & $\sim 20$ \\
\hline & & JJA & $-0.01 \pm 0.02$ & $3 \pm 1$ & $-2 \pm 1$ & $\sim 20$ \\
\hline & & SON & $0.03 \pm 0.02$ & $2 \pm 1$ & $-1 \pm 1$ & $\sim 20$ \\
\hline & AATSR & DJF & $-0.01 \pm 0.03$ & $1 \pm 2$ & $-2 \pm 2$ & - \\
\hline & & MAM & $-0.01 \pm 0.05$ & - & - & - \\
\hline & & JJA & $0.01 \pm 0.06$ & $-2 \pm 2$ & $0 \pm 1$ & - \\
\hline & & SON & $-0.03 \pm 0.03$ & $<1$ & $0 \pm 1$ & - \\
\hline \multirow[t]{8}{*}{ Ofu-olosega } & MODIS & DJF & $-0.03 \pm 0.02$ & $1 \pm 2$ & $0 \pm 1$ & - \\
\hline & & MAM & $-0.02 \pm 0.02$ & $3 \pm 2$ & $-1 \pm 1$ & - \\
\hline & & JJA & $-0.01 \pm 0.02$ & $0 \pm 2$ & $1 \pm 1$ & - \\
\hline & & SON & $-0.01 \pm 0.02$ & $1 \pm 2$ & $0 \pm 1$ & - \\
\hline & AATSR & DJF & $0.02 \pm 0.03$ & $-3 \pm 4$ & $-1 \pm 4$ & - \\
\hline & & MAM & $0.01 \pm 0.02$ & $2 \pm 6$ & $1 \pm 4$ & - \\
\hline & & JJA & $0.00 \pm 0.02$ & $0 \pm 8$ & $0 \pm 4$ & - \\
\hline & & SON & $0.01 \pm 0.02$ & $-2 \pm 6$ & $-1 \pm 4$ & - \\
\hline \multirow[t]{8}{*}{ Fiji } & MODIS & DJF & $0.04 \pm 0.06$ & $-1 \pm 3$ & $0 \pm 3$ & - \\
\hline & & MAM & - & - & - & - \\
\hline & & JJA & $0.04 \pm 0.06$ & $0 \pm 4$ & $0 \pm 1$ & - \\
\hline & & SON & $0.04 \pm 0.06$ & $1 \pm 5$ & $0 \pm 1$ & - \\
\hline & AATSR & DJF & $-0.03 \pm 0.04$ & $-6 \pm 6$ & $1 \pm 4$ & - \\
\hline & & MAM & - & - & - & - \\
\hline & & JJA & $0.06 \pm 0.05$ & $1 \pm 6$ & $3 \pm 6$ & - \\
\hline & & SON & $0.04 \pm 0.05$ & $3 \pm 6$ & $4 \pm 6$ & - \\
\hline
\end{tabular}

Cloud top pressures are between 860 and $440 \mathrm{mb}$.

${ }^{1}$ Difference between average upwind value ( -400 to $0 \mathrm{~km}$ ) and highest (AOD) or lowest (CER) downwind value.

2 Difference between average upwind and downwind values.

3 "Peak distance" refers to the approximate distance of peak AOD downwind from the volcanic vent. 

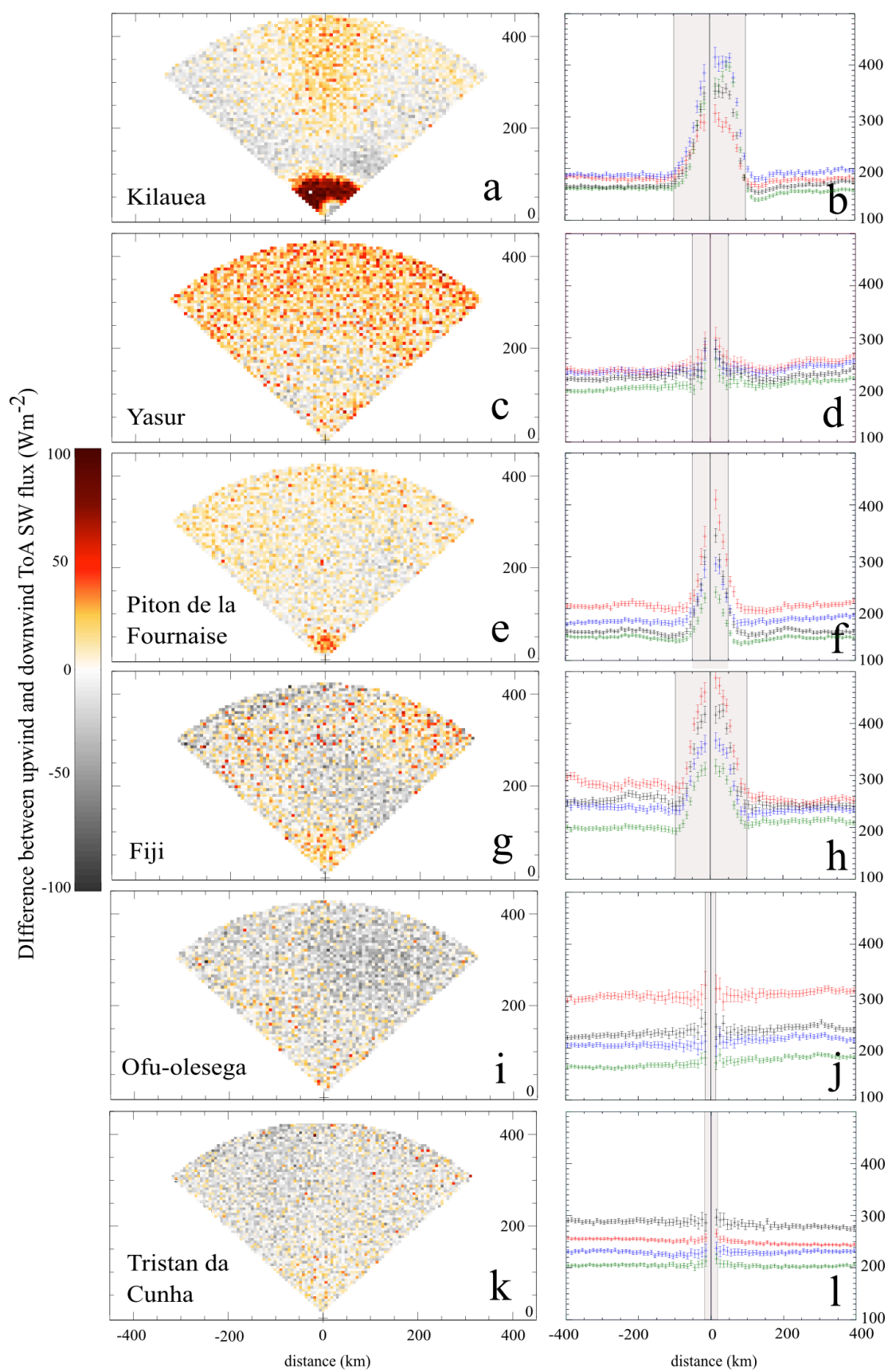

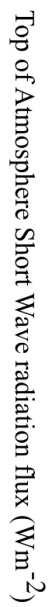

Figure 5. Scatter plots showing the difference between upwind and downwind Top of Atmosphere Short-Wave flux (a, c, e, g, i, k) for volcanoes and "controls". Positive values indicate higher upward SW flux downwind of the volcano. Profiles $(\mathbf{b}, \mathbf{d}, \mathbf{f}, \mathbf{h}, \mathbf{j}, \mathbf{l})$ indicate seasonal average SW fluxes for arcs of $\frac{\pi}{2}$ at equal distance upwind and downwind from the volcano or island. December-February is red, March-May is blue, June-August is green and September-November is black.

this decrease in CER downwind of Tristan da Cunha correlates well with a downwind increase in COD. At the active volcanoes (e.g. Fig. 3c or k), downwind CER remains low at greater distances from the vent than COD remains elevated. CER, though influenced by orographic processes, is more strongly affected by volcanogenic aerosol at Kīlauea and Piton de la Fournaise, and regional trends in cloud properties at Yasur. 


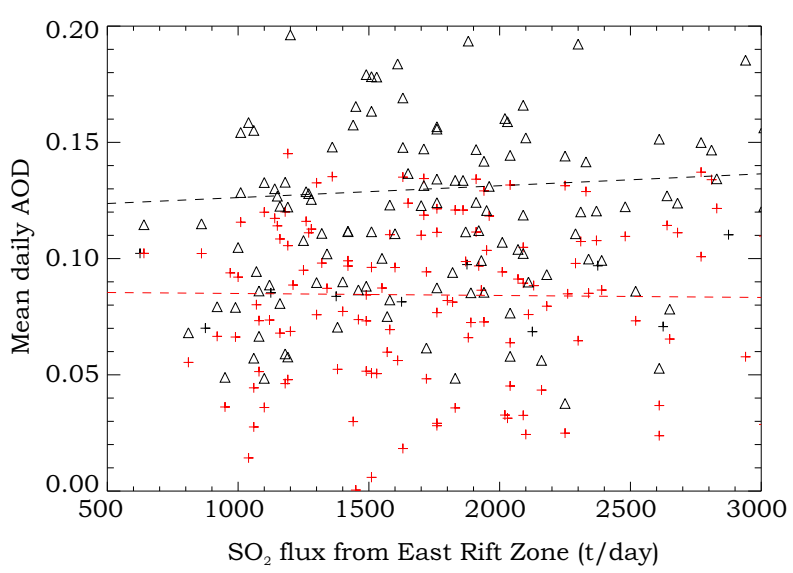

Figure 6. Comparison of $\mathrm{SO}_{2}$ flux from East Rift as reported by Elias and Sutton (2012), with AOD $(550 \mathrm{~nm})$ measurements from MODIS Aqua on the same day. The lack of relationship between ground- and satellite-based measurements may be due to several factors including dilution effects and differences in measurement times. Black triangles show MODIS AOD retrievals and the black dashed line indicates linear regression line. The red crosses show AOD values after de-trending for a linear relationship with wind speed, as demonstrated in Fig. 11. The red dashed line shows corrected linear regression.

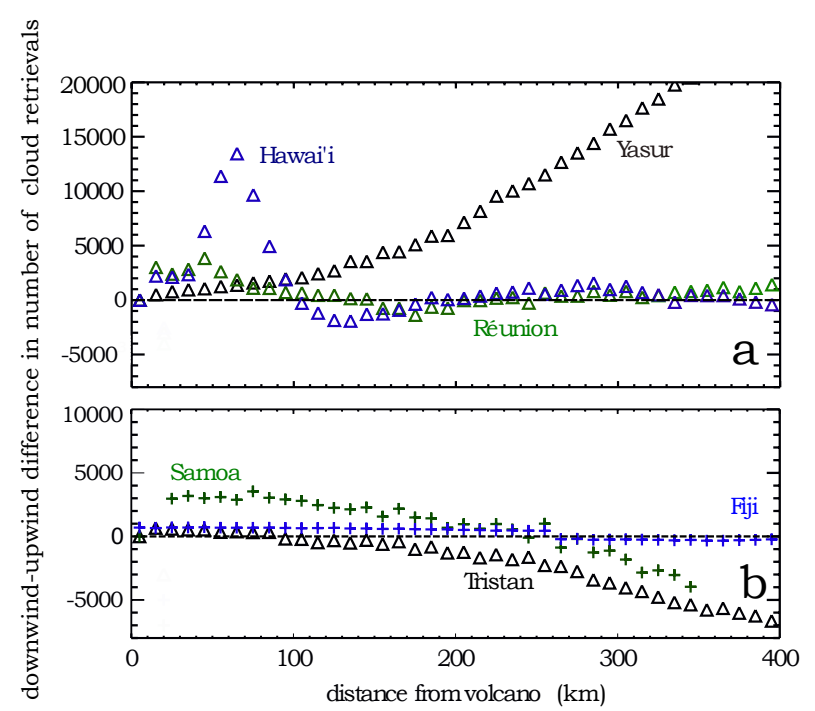

Figure 7. Plots of the difference between numbers of cloud retrievals (cloud fraction >0.2) downwind and upwind of volcanic vents (a) and island summits (b) from MODIS (Aqua), 2002-2008. At Hawai' $i$,and to some extent Réunion, there is a notable increase in the number of cloud retrievals made downwind relative to upwind within $100 \mathrm{~km}$ of the island.

\subsection{Consistency of measurements and sources of uncertainty}

The general trends in aerosol and cloud properties retrieved from MODIS and AATSR are consistent: both instruments show elevated AOD and suppressed CER downwind of the volcanoes but not control islands, and elevated COD over all land (Fig. 8, Table 2). However, seasonal differences vary between the instruments and AATSR results generally have much higher standard errors than MODIS due to longer repeat time ( 3 days relative to 1 day), shorter period of coverage (6 relative to 10 years) and consequently smaller sample size. The absolute values for CER are greater for MODIS than AATSR retrievals, likely due to the different penetration depths of the instrument wavelengths. The wavelengths most sensitive to CER are 1.6 and $2.1 \mu \mathrm{m}$ for AATSR ORAC and MODIS (Joint Atmosphere product) retrieval algorithms respectively. The shorter wavelength used by AATSR penetrates deeper into the clouds, so will sample smaller cloud droplets in a non-precipitating cloud, which typically have increasing cloud droplet size with height (Platnick, 2000; Sayer et al., 2011).

Standard error in seasonal and multiannual averages is greatest over land for both cloud and aerosol properties (large error bars on Figs. 3 and 4). This is the result of (a) fewer data points contributing to the mean (i.e. an arc of $\frac{\pi}{2}$ is shorter closer to the volcano) and (b) a greater spread in the retrieval values made over land. Observations made beyond the extent of the island are therefore most robust. The higher uncertainty in retrievals made over land may also contribute to the "anticipation" of the volcano, seen, for example, $\sim 50 \mathrm{~km}$ upwind of Kīlauea in Fig. 3a and Yasur in Fig. 3b. Uncertainties in ECMWF wind direction will smear upwinddownwind differences radially in our analysis. Isolated topographic peaks, such as these volcanoes, introduce perturbations to the regional wind fields, resulting in local turbulence near the volcano itself and local differences from the ECMWF wind fields $\left(\right.$ spatial resolution $=1.5^{\circ}$ ) used in our analysis.

As aerosol and cloud properties are both dependent on the same meteorological processes, there is a potential for spurious correlation between AOD and cloud properties, unrelated to volcanic aerosol. For example, cyclones are associated with both increased cloud fraction (Field and Wood, 2007) and increased AOD due to high relative humidity and wind speeds, resulting in elevated hygroscopic growth of aerosols (e.g. Seinfeld and Pandis, 1998; Twohy et al., 2009) as well as increased sea spray emission (e.g. Grandey et al., 2011). Artefacts in satellite retrievals of AOD under broken cloudy conditions may also lead to spurious correlations between aerosol and cloud properties (Grandey et al., 2013), but as we use retrievals from the full range of atmospheric conditions such effects should not have a significant impact on our results. False correlations between aerosol and cloud properties may also be introduced by analysis of satellite data over large regions containing significant variation in aerosol type, cloud regime and average synoptic conditions (Grandey and Stier, 2010). We limit the chance of our results being affected by spurious correlations due to spatial variations in climate by limiting measurements to regions of up to only $4^{\circ}$ across, 


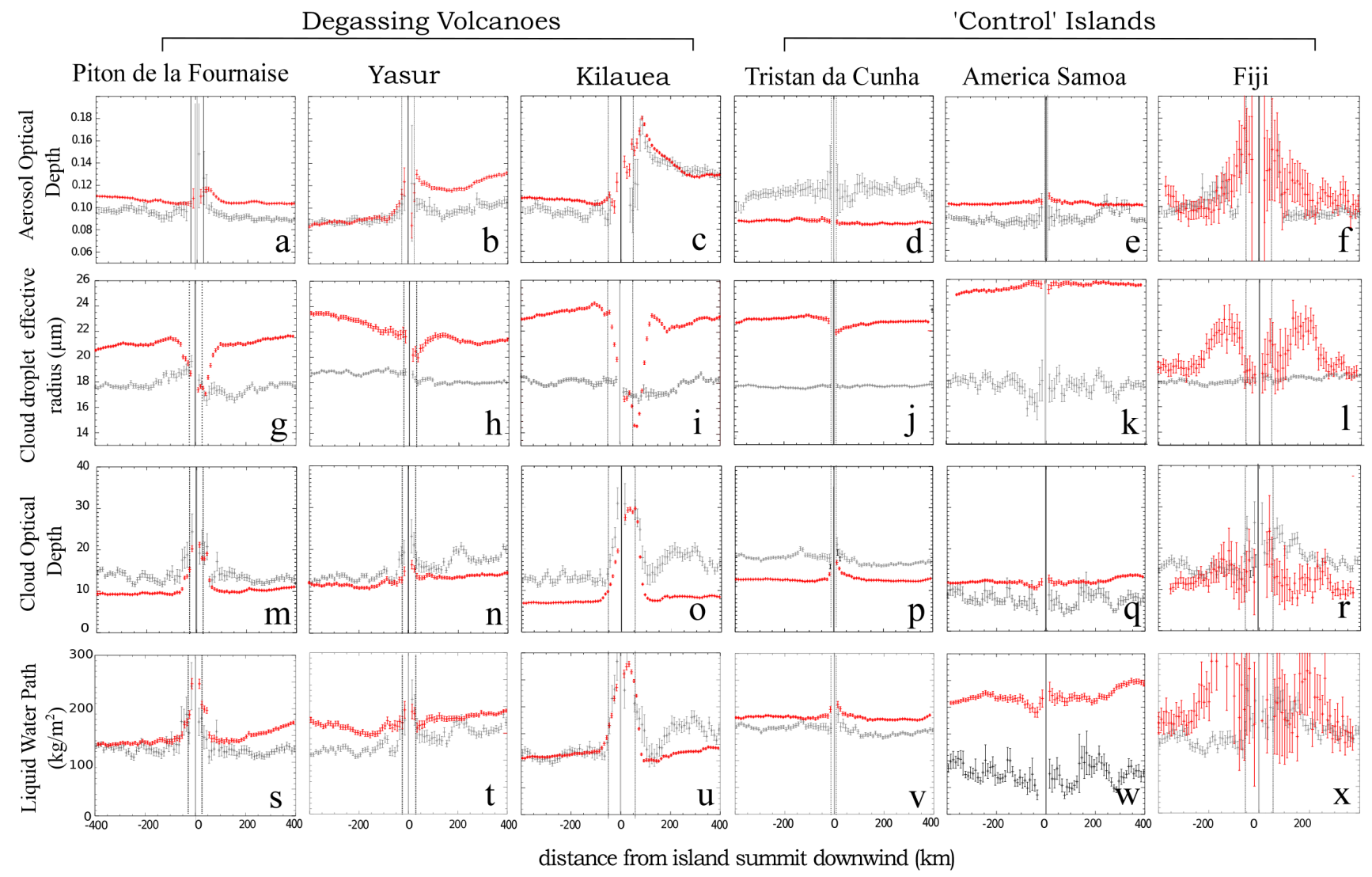

Figure 8. Comparison of multiannual averages for AATSR (grey) and MODIS (red) data, presented as in Fig. 3 and 4.

the largest regional size recommended by Grandey and Stier (2010) for analysis of AIE. Only in data from the $4^{\circ}$ surrounding Yasur do we observe a systematic regional trend in aerosol properties. There were many more cloud retrievals (cloud fraction $>0.2$, Fig. 7) downwind than upwind, though COD remained similar. This means that although aerosols are elevated downwind of Yasur, there is not evidence of statistically significant AIE.

\section{Discussion}

\subsection{Observations of volcanic aerosol}

The identification of VAIE is easiest where other sources of aerosol are low. We assume that for the islands discussed here, primary sea spray aerosol dominates aerosol populations (e.g. Sayer et al., 2012; Smirnov et al., 2012; Huang et al., 2010). We test this assumption by examining the linear relationships between mean daily AOD and surface wind speeds within $50 \mathrm{~km}$ radius of the volcanoes (Fig. 11). The slopes of the linear regression between AOD and binned wind speed take values ranging from 0.003-0.005 for Kîlauea, Yasur and La Réunion, respectively in Fig. 11. This is within the range found by Smirnov et al. (2012) from examination of ship-borne sun photometer AOD measurements and near-surface wind speeds (0.004-0.005). This supports the assumption that sea spray is the most important background aerosol at these volcanoes, rather than, for example, organic carbon or mineral dust from the islands.

Time series of daily AOD from MODIS data all show a large day-to-day variability. This is partially attributable to the amount of both sea spray and volcanogenic aerosol being heavily dependent on synoptic conditions. Although the emission of volcanic gases is independent of atmospheric conditions, the oxidising agents and reaction rates for the formation of $\mathrm{SO}_{4}^{2-}$ from $\mathrm{SO}_{2}$ are dependent on atmospheric conditions such as supersaturation and solar irradiation levels (Eatough et al., 1995). The formation of aerosol may take place in a different manner in clear and cloudy conditions, and dilution effects will also vary with wind speed and direction. The emission of volcanic gases also varies through time. While at Kîlauea, $\mathrm{SO}_{2}$ emission is passive and accompanies long-lived flows and lava lake activity, at Yasur gas flux and composition varies more rapidly according the stage of Strombolian explosion. At Piton de la Fournaise intereruptive flux is low, but $\mathrm{SO}_{2}$ emission accompanies frequent minor explosions and lava flows. There is a general correlation between net downwind aerosol at the three volcanoes 


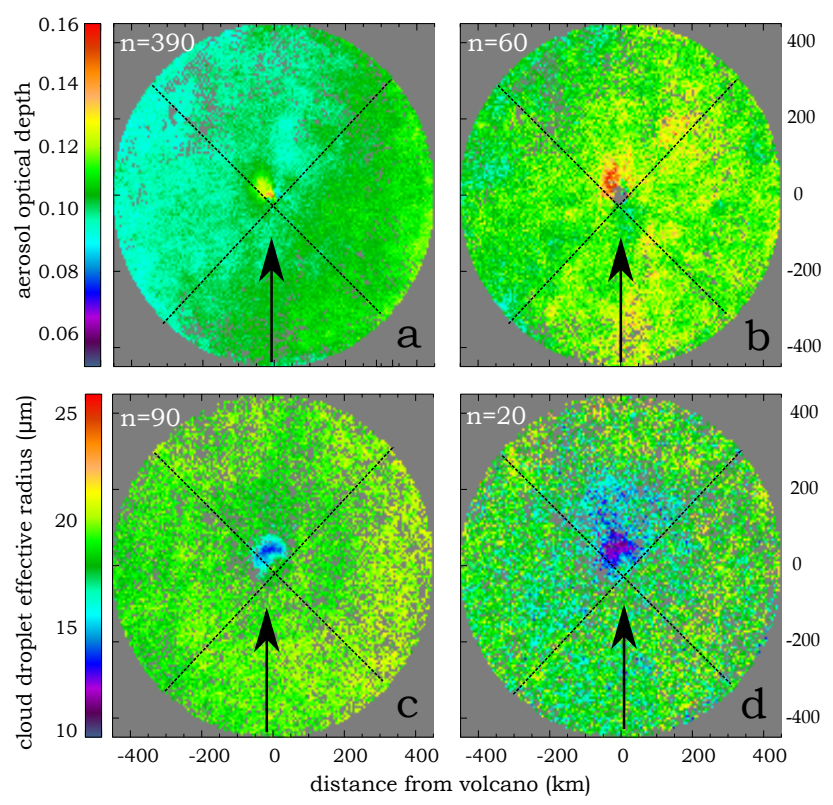

Figure 9. Scatterplots show the average of rotated MODIS Aqua AOD $(\mathbf{a}, \mathbf{b})$ and CER $(\mathbf{c}, \mathbf{d})$ at Piton de la Fournaise during intereruptive (a, c) and eruptive (b, d) periods, 2002-2008. Cloud top pressures are $860-440 \mathrm{mb}$. The volcano summit is at $(0,0)$ and arrows indicate wind direction. Downwind is the upper quadrant in each case. $n$ values refer to the average sample size in each image. Only data where sample sizes exceed 15 and relative standard deviations are less than $10 \%$ are shown.

and average background (inter-eruptive) $\mathrm{SO}_{2}$ flux (e.g. Tables 1 and 2).

\subsection{Volcanic aerosol and cloud interaction}

The impact of volcanogenic aerosol depends on synoptic conditions and the state of any pre-existing cloud. Secondary sulfate aerosol formed from ambient reactions of volcanic $\mathrm{SO}_{2}$ are typically $<0.1 \mu \mathrm{m}$ in diameter, and are therefore too small to act as $\mathrm{CCN}$ where the level of supersaturation is low (e.g. Pierce and Adams, 2007). Aerosol from shipping most commonly results in tracks of lower CER where the aerosol plume is able to mix directly with an overlying cloud deck before major dispersal. Typical ship tracks form when the boundary layer is shallow $(<800 \mathrm{~m})$, wind speeds are moderate, relative humidity is high and the difference in temperature between air and sea is low (Durkee et al., 2000). The impact of additional $\mathrm{CCN}$ on orographic cloud has been less well studied, and conditions most likely to result in cloud brightening are unclear (Muhlbauer et al., 2010).

All of the islands investigated here are in regions where the free atmosphere is dominated by trade winds, except Tristan da Cunha, where westerlies dominate. We expect that the measurements of cloud properties are most commonly from decks of marine stratocumulus over the oceans, with contributions from orographic cloud over land and in the islands' wakes. As our results consist of seasonal and multiannual averages of retrievals, they contain contributions from days with a range of meteorological conditions (Mean COD and cloud top pressures for MODIS data 2002-2013 are shown in the Supplement). The mean values for COD and CER presented here therefore capture net conditions and may not bear a resemblance to the atmospheric processes on any particular day. Our measurements of time-averaged impact would be complemented by case-by-case analysis of volcanic tracks (e.g. Gassó, 2008) to improve our understanding of the influence of atmospheric conditions and emission characteristics on cloud properties.

\subsection{Evidence for volcanic aerosol indirect effects}

The anticorrelation between AOD and CER values downwind of the degassing volcanoes provides strong evidence for a first indirect effect at Kīlauea and Piton de la Fournaise. This is confirmed by the perturbation to ToA upward SW flux downwind of the active volcanoes seen in CERES data. At all the active volcanoes minimum CER is found at similar downwind distance as peak AOD in averaged retrieval data. The difference between background (upwind) CER and the minimum value found downwind is greatest at Kîlauea (up to $-8 \mu \mathrm{m}$, decrease of $35 \%$ ) and lower at Yasur and Piton de la Fournaise (up to $-4 \mu \mathrm{m}$, decrease of $18 \%$ ). This difference far exceeds the expected uncertainty in MODIS CER retrievals of $2-3.5 \%$ (Platnick et al., 2003). In common with the persistent downwind elevation in AOD, CER at Kîlauea and Yasur remains lower than upwind values at least as far as $400 \mathrm{~km}$ downwind, while CER returns to its average upwind value within $100 \mathrm{~km}$ at Réunion. Droplets in "clean" clouds upwind of the volcanoes have average droplet effective radii of $21-22 \mu \mathrm{m}$.

The presence of secondary AIE are harder to demonstrate. Liquid water path (LWP, $\mathrm{kg} \mathrm{m}^{-2}$ ) reaches its peak value within $\sim 50 \mathrm{~km}$ of the volcanic vents and is very slightly elevated downwind relative to upwind at the volcanoes (Fig. 3 and 4). This could indicate an increase in cloud lifetime due to drizzle suppression (e.g. Lohmann et al., 2005), but it may also be the consequence of the contribution of cooling and condensing water vapour emitted from the volcano. At Kìlauea, and to some extent Piton de la Fournaise, there were an elevated number of cloud retrievals with cloud fraction $>0.2$ downwind relative to upwind (Fig. 7). Water vapour flux at Yasur exceeds $13 \times 10^{3} \mathrm{Mg} \mathrm{day}^{-1}$ (Métrich et al., 2011). Emissions of water vapour into the atmosphere at Kîlauea and Piton de la Fournaise will be even greater due to the additional contribution of evaporated seawater where lava flows meet the sea (e.g. Edmonds and Gerlach, 2006; Gouhier and Coppola, 2011). The condensation of evaporated seawater may result in an increase in LWP content downwind that would mask any evidence of secondary AIE.

In spite of the strong correlation, our MODIS and AATSR measurements do not allow a direct measurement of the 

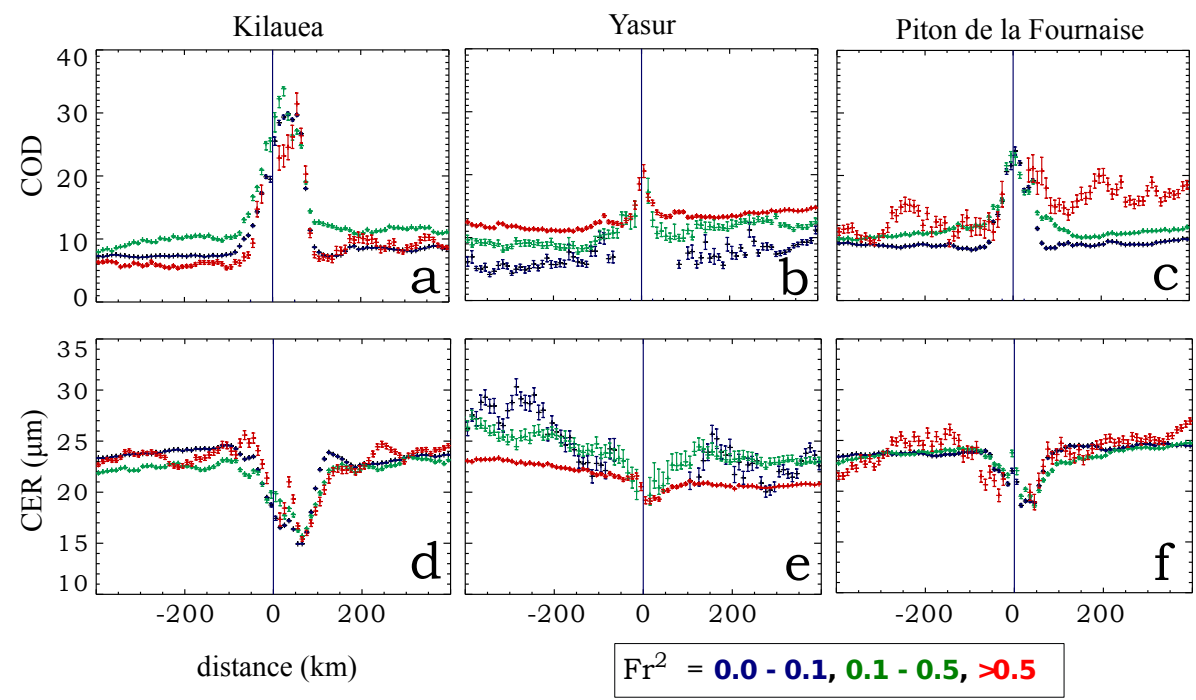

Figure 10. Profiles showing average COD (a-c) and CER (d-f) at Kīlauea, Yasur and Piton de la Fournaise, separated according to Froude number squared $\left(F r^{2}\right)$ as estimated from ECMWF data. $F r^{2}=0-0.1$ is blue, $F r^{2}=0.1-0.5$ is green and $F r^{2}>0.5$ is red.

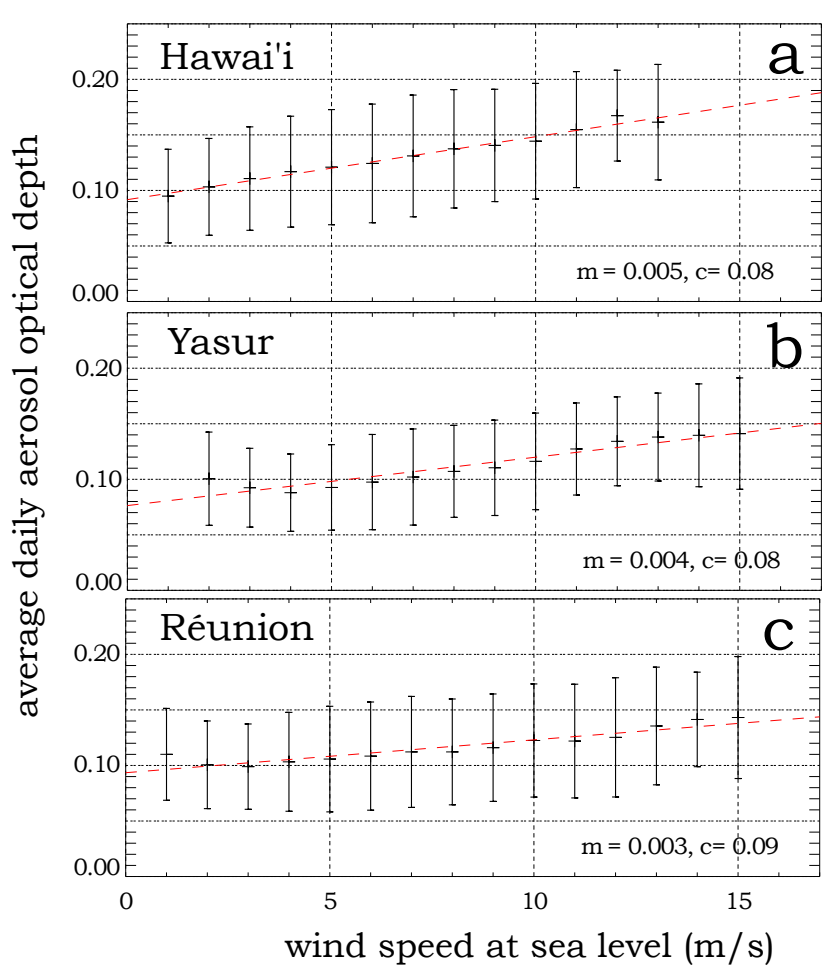

Figure 11. Daily average AOD at $550 \mathrm{~nm}$ measured from MODIS, Aqua between 2002 and 2008 with $50 \mathrm{~km}$ of the coasts of (a) Hawai'i, (b) Yasur and (c) Réunion plotted as a function of horizontal wind speed at sea level from ECMWF. Error bars show the standard deviation in AODs for bin intervals of $1 \mathrm{~m} \mathrm{~s}^{-1}$.

Twomey effect because retrievals of aerosol and cloud properties are mutually exclusive (i.e. aerosol properties are retrieved only where pixels are not flagged as cloud). However, the increase in average downwind ToA upward SW flux seen in CERES data for all sky conditions shows a radiative impact over a similar area to the downwind cloud and aerosol perturbations, providing additional evidence of a first indirect effect associated with volcanic aerosol.

\section{Extrapolating to global volcanic aerosol indirect effects}

Elevated AOD and suppressed CER are observed over a decade downwind of three persistently active volcanoes with different eruptive characteristics: Kïlauea (strong degassing), Yasur (Strombolian eruptions) and Piton de la Fournaise (minor explosions and lava flows). Top of Atmosphere Short Wave radiative flux is apparently elevated by at least $10 \mathrm{Wm}^{-2}$ downwind of all three degassing volcanoes at distances $>150 \mathrm{~km}$, and is even higher within $100 \mathrm{~km}$ downwind of Kỉlauea and Piton de la Fournaise. Time-averaged cloud data at three "control" islands showed no significant suppression of CER downwind of the islands or perturbation to ToA upward SW flux exceeding $\pm 10 \mathrm{Wm}^{-2}$.

Our approach builds on previous studies of volcano tracks during periods of elevated activity (Gassó, 2008; Yuan et al., 2011) by estimating average volcanic impact over 6-10 years. This is a step towards the measurement of the longterm impact of persistent volcanic activity in the presentday atmosphere. In the three test cases described here, we observe some general trends that could be extrapolated to other volcanoes. High average downwind AOD is linked with high background $\mathrm{SO}_{2}$ flux. Although daily groundbased measurements of $\mathrm{SO}_{2}$ do not necessarily correlate with daily satellite retrievals of $\mathrm{AOD}$, average background $\mathrm{SO}_{2}$ flux at the three volcanoes is proportional to time-averaged 
upwind-downwind difference in AOD (Tables 1 and 2). Both the greatest upwind-downwind differences in AOD and CER and the greatest distance to minimum CER were found at Kilauea, the volcano with the greatest $\mathrm{SO}_{2}$ flux.

Of the 49 continuously erupting volcanoes for which Andres and Kasgnoc (1998) present $\mathrm{SO}_{2}$ fluxes, only 8 are islands further than $\sim 50 \mathrm{~km}$ from the nearest land mass and together contribute $\sim 14 \%$ of the $\mathrm{SO}_{2}$ flux in the compilation. Our observations at Kîlauea and Yasur alone capture the local impact of about half of these emissions. The remaining $\mathrm{SO}_{2}$ flux from continuously degassing volcanoes originates on the continents (24 volcanoes) or within $\sim 50 \mathrm{~km}$ of the nearest large landmass (17 volcanoes). These "coastal" volcanoes, including Etna, Bagana and Sakura-jima, emit almost 50\% of global continuous emissions (Andres and Kasgnoc, 1998). Observations of AIE in continental or coastal settings may be achievable using trajectory analysis of air parcels from the volcano to allow comparison of aerosol-laden atmosphere to average background conditions. Our observations of VAIE at Piton de la Fournaise demonstrate that active volcanoes without a constant $\mathrm{SO}_{2}$ flux to the atmosphere also have an impact on time-averaged local cloud properties. A complete inventory of tropospheric cloud alteration by volcanoes should therefore also include emissions associated with minor explosions.

The VAIE observed in this study is unlikely to be representative of the average present-day impact of volcanoes worldwide. Importantly, the impact of additional aerosols on cloud microphysics is greater for pristine clouds than for polluted regions (e.g. Lohmann et al., 2005; Rosenfeld et al., 2008). The change in cloud droplet size downwind of Kîlauea, Yasur and Piton de la Fournaise is expected to be large relative to that for volcanoes that emit aerosol into heavily polluted cloud decks (e.g. Etna, Masaya). However, these observations of the most pristine parts of the Earth's present-day atmosphere are likely to be the best observable analogue of pre-industrial aerosol effects.

\section{The Supplement related to this article is available online at doi:10.5194/acp-14-10601-2014-supplement.}

Acknowledgements. We thank Santiago Gassó for useful discussions at the inception of this project and during this paper's preparation. SKE is funded by the UK National Environmental Research Council through the COMET/NCEO and STREVA programmes. RGG, TAM and EC are also supported by COMET/NCEO. GRAPE data are hosted by the BADC and MODIS data are hosted by NASA LAADS.

Edited by: M. Ammann

\section{References}

Ackerman, A. S., Toon, O. B., Taylor, J. P., Johnson, D. W., Hobbs, P. V., and Ferek, R. J.: Effects of Aerosols on Cloud Albedo: Evaluation of Twomey's Parameterization of Cloud Susceptibility Using Measurements of Ship Tracks, J. Atmos. Sci., 57, 2684-2695, doi:10.1175/15200469(2000)057<2684:EOAOCA>2.0.CO;2, 2000.

Ackerman, A. S., Kirkpatrick, M. P., Stevens, D. E., and Toon, O. B.: The impact of humidity above stratiform clouds on indirect aerosol climate forcing, Nature, 432, 1014-1017, 2004.

Ackerman, S., Holz, R., Frey, R., Eloranta, E., Maddux, B., and McGill, M.: Cloud detection with MODIS. Part II: validation, J. Atmos. Ocean. Tech., 25, 1073-1086, doi:10.1175/2007JTECHA1053.1, 2008.

Albrecht, B.: Aerosols, cloud microphysics, and fractional cloudiness, Science, New York, NY, 245, 1227-1230, doi:10.1126/science.245.4923.1227, 1989.

Allen, A., Oppenheimer, C., Ferm, M., Baxter, P., Horrocks, L., Galle, B., McGonigle, A., and Duffell, H.: Primary sulfate aerosol and associated emissions from Masaya Volcano, Nicaragua, J. Geophys. Res., 107, 4682, doi:10.1029/2002JD002120, 2002.

Andreae, M. O.: Aerosols before pollution, Science (Washington), 315, 50-51, doi:10.1126/science.1136529, 2007.

Andres, R. and Kasgnoc, A.: A time-averaged inventory of subaerial volcanic sulfur emissions, J. Geophys. Res., 103, 25251-251998.

Bani, P. and Lardy, M.: Sulphur dioxide emission rates from Yasur volcano, Vanuatu archipelago, Geophys. Res. Lett., 34, L20309, doi:10.1029/2007GL030411, 2007.

Bani, P., Oppenheimer, C., Allard, P., Shinohara, H., Tsanev, V., Carn, S., Lardy, M., and Garaebiti, E.: First estimate of volcanic $\mathrm{SO}_{2}$ budget for Vanuatu island arc, Journal of Volcanology and Geothermal Research, 211, 36-46, doi:10.1016/j.jvolgeores.2011.10.005, 2012.

Bhugwant, C., Siéja, B., Bessafi, M., Staudacher, T., and Ecormier, J.: Atmospheric sulfur dioxide measurements during the 2005 and 2007 eruptions of the Piton de La Fournaise volcano: Implications for human health and environmental changes, Journal of Volcanology and Geothermal Research, 184, 208-224, doi:10.1016/j.jvolgeores.2009.04.012, 2009.

Brenguier, J., Pawlowska, H., and Schüller, L.: Cloud microphysical and radiative properties for parameterization and satellite monitoring of the indirect effect of aerosol on climate, J. Geophys. Res., 108, 8632, doi:10.1029/2002JD002682, 2003.

Campmany, E., Grainger, R. G., Dean, S. M., and Sayer, A. M.: Automatic detection of ship tracks in ATSR-2 satellite imagery, Atmos. Chem. Phys., 9, 1899-1905, doi:10.5194/acp-9-1899-2009, 2009.

Carslaw, K. S., Lee, L. A., Reddington, C. L., Pringle, K. J., Rap, A., Forster, P. M., Mann, G. W., Spracklen, D. V., Woodhouse, M. T., Regayre, L., and Pierce, J. R.: Large contribution of natural aerosols to uncertainty in indirect forcing, Nature, 503, 67-71, doi:10.1038/nature12674, 2013.

Chen, Y.-C., Christensen, M. W., Xue, L., Sorooshian, A., Stephens, G. L., Rasmussen, R. M., and Seinfeld, J. H.: Occurrence of lower cloud albedo in ship tracks, Atmos. Chem. Phys., 12, 8223-8235, doi:10.5194/acp-12-8223-2012, 2012.

Christensen, M. W. and Stephens, G. L.: Microphysical and macrophysical responses of marine stratocumulus polluted by under- 
lying ships: Evidence of cloud deepening, J. Geophys. Res.Atmos., 116, D03201, doi:10.1029/2010JD014638, 2011.

Coppola, D., Piscopo, D., Staudacher, T., and Cigolini, C.: Lava discharge rate and effusive pattern at Piton de la Fournaise from MODIS data, Journal of Volcanology and Geothermal Research, 184, 174-192, doi:10.1016/j.jvolgeores.2008.11.031, 2009.

Dee, D. P., Uppala, S. M., Simmons, A. J., Berrisford, P., Poli, P., Kobayashi, S., Andrae, U., Balmaseda, M. A., Balsamo, G., Bauer, P., Bechtold, P., Beljaars, A. C. M., van de Berg, L., Bidlot, J., Bormann, N., Delsol, C., Dragani, R., Fuentes, M., Geer, A. J., Haimberger, L., Healy, S. B., Hersbach, H., Hólm, E. V., Isaksen, L., Kållberg, P., Köhler, M., Matricardi, M., McNally, A. P., Monge-Sanz, B. M., Morcrette, J.-J., Park, B.-K., Peubey, C., de Rosnay, P., Tavolato, C., Thépaut, J.-N., and Vitart, F.: The ERA-Interim reanalysis: configuration and performance of the data assimilation system, Q. J. Roy. Meteorol. Soc., 137, 553597, doi:10.1002/qj.828, 2011.

Dentener, F., Kinne, S., Bond, T., Boucher, O., Cofala, J., Generoso, S., Ginoux, P., Gong, S., Hoelzemann, J. J., Ito, A., Marelli, L., Penner, J. E., Putaud, J.-P., Textor, C., Schulz, M., van der Werf, G. R., and Wilson, J.: Emissions of primary aerosol and precursor gases in the years 2000 and 1750 prescribed data-sets for AeroCom, Atmos. Chem. Phys., 6, 4321-4344, doi:10.5194/acp-64321-2006, 2006.

Di Muro, A., Aiuppa, A., Burton, M., Metrich, N., Allard, P., Fougeroux, T., Giudice, G., and Guida, R.: Intra-eruptive gas emissions and shallow magma storage after the 2007 summit caldera collapse of Piton de la Fournaise, Reunion island., in: EGU General Assembly Conference Abstracts, edited by Abbasi, A. and Giesen, N., vol. 14 of EGU General Assembly Conference Abstracts, p. 2761, 2012.

Durkee, P. A., Chartier, R. E., Brown, A., Trehubenko, E. J., Rogerson, S. D., Skupniewicz, C., Nielsen, K. E., Platnick, S., and King, M. D.: Composite Ship Track Characteristics, J. Atmos. Sci., 57, 2542-2553, doi:10.1175/15200469(2000)057<2542:CSTC>2.0.CO;2, 2000.

Eatough, D. J., Caka, F. M., and Farber, R. J.: The conversion of $\mathrm{SO}_{2}$ to sulfate in the atmosphere, Isr. J. Chem., 34, 301-314, doi:10.1002/ijch.199400034, 1995.

Edmonds, M. and Gerlach, T.: The airborne lava-seawater interaction plume at Kîlauea Volcano, Hawaii, Earth Planet. Sc. Lett., 244, 83-96, doi:10.1016/j.eps1.2006.02.005, 2006.

Elias, T. and Sutton, A. J.: Sulfur dioxide emission rates from Kilauea Volcano, Hawai'i, 2007-2010, U.S. Geological Survey Open-File Report, 1107, 25 pp., available at: http://pubs.usgs. gov/of/2012/1107/, 2012.

Field, P. R. and Wood, R.: Precipitation and Cloud Structure in Midlatitude Cyclones, J. Climate, 20, 233, doi:10.1175/JCLI3998.1, 2007.

Garofalo, K., Staudacher, T., Ferrazzini, V., Kowalski, P., Boissier, P., Dupont, A., Peltier, A., Villemant, B., and Boudon, G.: Eruptive SO2-plume measurements at Piton de la Fournaise (Ile de La Réunion) by stationary NOVAC scanning MAX-DOAS instruments, in: EGU General Assembly Conference Abstracts, 11, p. $12113,2009$.

Gassó, S.: Satellite observations of the impact of weak volcanic activity on marine clouds, J. Geophys. Res.-Atmos., 113, D14S19, doi:10.1029/2007JD009106, 2008.
Geier, E., Green, R., Kratz, D., Minnis, P., Miller, W., Nolan, S., and Franklin, C.: CERES data management system: Single Satellite Footprint TOA/surface fluxes and clouds (SSF) collection document, release 2, version 1, $212 \mathrm{pp}$. and appendixes, NASA Langley Res. Cent., Hampton, Va, Radiat. and Aerosol Branch, Atmos. Sci. Res., NASA Langley Res. Cent., Hampton, Va, available at: http://asd-www.larc.nasa.gov/ceres/collect_guide/SSF_ CG.pdf), 2003.

Gouhier, M. and Coppola, D.: Satellite-based evidence for a large hydrothermal system at Piton de la Fournaise volcano (Reunion Island), Geophys. Res Lett., 38, L02302, doi:10.1029/2010GL046183, 2011.

Graf, H., Langmann, B., and Feichter, J.: The contribution of Earth degassing to the atmospheric sulfur budget, Chem. Geol., 147, 131-145, doi:10.1016/S0009-2541(97)00177-0, 1998.

Grandey, B. S. and Stier, P.: A critical look at spatial scale choices in satellite-based aerosol indirect effect studies, Atmos. Chem. Phys., 10, 11459-11470, doi:10.5194/acp-10-11459-2010, 2010.

Grandey, B. S., Stier, P., Wagner, T. M., Grainger, R. G., and Hodges, K. I.: The effect of extratropical cyclones on satelliteretrieved aerosol properties over ocean, Geophys. Res. Lett., 38, L13805, doi:10.1029/2011GL047703, 2011.

Grandey, B. S., Stier, P., and Wagner, T. M.: Investigating relationships between aerosol optical depth and cloud fraction using satellite, aerosol reanalysis and general circulation model data, Atmos. Chem. Phys., 13, 3177-3184, doi:10.5194/acp-13-31772013, 2013.

Halmer, M., Schmincke, H., and Graf, H.: The annual volcanic gas input into the atmosphere, in particular into the stratosphere: a global data set for the past 100 years, Journal of Volcanology and Geothermal Research, 115, 511-528, doi:10.1016/S03770273(01)00318-3, 2002.

Hansen, J., Sato, M., Ruedy, R.: Radiative forcing and climate response, J. Geophys. Res., 102, 6831-6864, doi:10.1029/96JD03436, 1997.

Houze, R. A. J.: Cloud dynamics, vol. 53, Access Online via Elsevier, 1994.

Huang, H., Thomas, G. E., and Grainger, R. G.: Relationship between wind speed and aerosol optical depth over remote ocean, Atmos. Chem. Phys., 10, 5943-5950, doi:10.5194/acp-10-59432010, 2010.

Jiusto, J.: Aerosol and cloud microphysics measurements in Hawai'i, Tellus, 19, 359-368, 1967.

Khokhar, M., Frankenberg, C., van Roozendael, M., Beirle, S., Kühl, S., Richter, A., Platt, U., and Wagner, T.: Satellite observations of atmospheric $\mathrm{SO}_{2}$ from volcanic eruptions during the time-period of 1996-2002, Adv. Space Res., 36, 879-887, doi:10.1016/j.asr.2005.04.114, 2005.

Lee, L. A., Pringle, K. J., Reddington, C. L., Mann, G. W., Stier, P., Spracklen, D. V., Pierce, J. R., and Carslaw, K. S.: The magnitude and causes of uncertainty in global model simulations of cloud condensation nuclei, Atmos. Chem. Phys., 13, 8879-8914, doi:10.5194/acp-13-8879-2013, 2013.

Levy, R. C., Mattoo, S., Munchak, L. A., Remer, L. A., Sayer, A. M., Patadia, F., and Hsu, N. C.: The Collection 6 MODIS aerosol products over land and ocean, Atmos. Meas. Tech., 6, 29893034, doi:10.5194/amt-6-2989-2013, 2013. 
Lohmann, U. and Feichter, J.: Global indirect aerosol effects: a review, Atmos. Chem. Phys., 5, 715-737, doi:10.5194/acp-5-7152005, 2005.

Martin, G., Ringer, M., Pope, V., Jones, A., Dearden, C., and Hinton, T.: The physical properties of the atmosphere in the new Hadley Centre Global Environmental Model (HadGEM1), Part I: Model description and global climatology, J. Clim., 19, 12741301, doi:10.1175/JCLI3636.1, 2006.

Martin, R., Mather, T., Pyle, D., Power, M., Allen, A., Aiuppa, A., Horwell, C., and Ward, E.: Composition-resolved size distributions of volcanic aerosols in the Mt. Etna plumes, J. Geophys. Res., 113, D17211, doi:10.1029/2007JD009648, 2008.

Mather, T., McCabe, J., Rai, V., Thiemens, M., Pyle, D., Heaton, T. H. E., Sloane, H. J., and Fern, G. R.: Oxygen and Sulfur isotopic composition of volcanic sulfate aerosol at the point of emission, J. Geophy. Res., 111, D18205, doi:10.1029/2005JD006584, 2006.

Mather, T., Witt, M., Pyle, D., Quayle, B., Aiuppa, A., Bagnato, E., Martin, R., Sims, K., Edmonds, M., Sutton, A., and Ilyinskaya, E.: Halogens and trace metal emissions from the ongoing 2008 summit eruption of Kỉlauea volcano, Hawai'i, Geochim. Cosmochim. Ac., 83, 292-323, doi:10.1016/j.gca.2011.11.029, 2012.

Mather, T. A., Pyle, D. M., and Oppenheimer, C.: Tropospheric volcanic aerosol, Geoph. Monog. Series, 139, 189-212, doi:10.1029/139GM12, 2003.

Mather, T. A., Tsanev, V. I., Pyle, D. M., McGonigle, A. J. S., Oppenheimer, C., and Allen, A. G.: Characterization and evolution of tropospheric plumes from Lascar and Villarrica volcanoes, Chile, J. Geophys. Res.-Atmos., 109, D21303, doi:10.1029/2004JD004934, 2004.

Métrich, N., Allard, P., Aiuppa, A., Bani, P., Bertagnini, A., Shinohara, H., Parello, F., Di Muro, A., Garaebiti, E., Belhadj, O., and Massare, D.: Magma and volatile supply to post-collapse volcanism and block resurgence in Siwi Caldera (Tanna Island, Vanuatu Arc), J. Petrol., 52, 1077-1105, 2011.

Muhlbauer, A., Hashino, T., Xue, L., Teller, A., Lohmann, U., Rasmussen, R. M., Geresdi, I., and Pan, Z.: Intercomparison of aerosol-cloud-precipitation interactions in stratiform orographic mixed-phase clouds, Atmos. Chem. Phys., 10, 8173 8196, doi:10.5194/acp-10-8173-2010, 2010.

Oppenheimer, C., Scaillet, B., and Martin, R. S.: Sulfur degassing from volcanoes: source conditions, surveillance, plume chemistry and earth system impacts, Reviews in Mineralogy and Geochemistry, 73, 363-421, doi:10.2138/rmg.2011.73.13, 2011.

Peltier, A., Bachèlery, P., and Staudacher, T.: Magma transport and storage at Piton de La Fournaise (La Réunion) between 1972 and 2007: A review of geophysical and geochemical data, Journal of Volcanology and Geothermal Research, 184, 93-108, doi:10.1016/j.jvolgeores.2008.12.008, 2009.

Peters, K., Quaas, J., and Graß1, H.: A search for large-scale effects of ship emissions on clouds and radiation in satellite data, J. Geophys. Res.-Atmos., 116, D24205, doi:10.1029/2011JD016531, 2011.

Pierce, J. R. and Adams, P. J.: Efficiency of cloud condensation nuclei formation from ultrafine particles, Atmos. Chem. Phys., 7, 1367-1379, doi:10.5194/acp-7-1367-2007, 2007.
Platnick, S.: Vertical photon transport in cloud remote sensing problems, J. Geophys. Res.-Atmos., 105, 22919-22935, doi:10.1029/2000JD900333, 2000.

Platnick, S., King, M. D., Ackerman, S. A., Menzel, W. P., Baum, B. A., Riédi, J. C., and Frey, R. A.: The MODIS cloud products: Algorithms and examples from Terra, Geoscience and Remote Sensing, IEEE Transactions on, 41, 459473, doi:10.1109/TGRS.2002.808301, 2003.

Porter, J. N., Horton, K. A., Mouginis-Mark, P. J., Lienert, B., Sharma, S. K., Lau, E., Sutton, A. J., Elias, T., and Oppenheimer, C.: Sun photometer and lidar measurements of the plume from the Hawai'i Kilauea Volcano Pu'u O'o vent: Aerosol flux and $\mathrm{SO}_{2}$ lifetime, Geophys. Res. Lett., 29, 1783, doi:10.1029/2002GL014744, 2002.

Poulsen, C. A., Siddans, R., Thomas, G. E., Sayer, A. M., Grainger, R. G., Campmany, E., Dean, S. M., Arnold, C., and Watts, P. D.: Cloud retrievals from satellite data using optimal estimation: evaluation and application to ATSR, Atmos. Meas. Tech., 5, 1889-1910, doi:10.5194/amt-5-1889-2012, 2012.

Quaas, J., Stevens, B., Stier, P., and Lohmann, U.: Interpreting the cloud cover - aerosol optical depth relationship found in satellite data using a general circulation model, Atmos. Chem. Phys., 10, 6129-6135, doi:10.5194/acp-10-6129-2010, 2010.

Remer, L. A., Kaufman, Y., Tanré, D., Mattoo, S., Chu, D., Martins, J., Li, R.-R., Ichoku, C., Levy, R., Kleidman, R., Eck, T. F., Vermote, E. and Holben, B. N.: The MODIS aerosol algorithm, products, and validation, J. Atmos. Sci., 62, 947-973, doi:10.1175/JAS3385.1, 2005.

Robock, A.: The climatic aftermath, Science, 295, 1242-1244, doi:10.1126/science.1069903, 2002.

Rosenfeld, D., Lohmann, U., Raga, G., O’Dowd, C., Kulmala, M., Fuzzi, S., Reissell, A., and Andreae, M.: Flood or drought: How do aerosols affect precipitation?, Science, 321, 1309-1313, doi:10.1126/science.1160606, 2008.

Rosenfeld, D., Sherwood, S., Wood, R., and Donner, L.: Climate Effects of Aerosol-Cloud Interactions, Science, 343, 379-380, doi:10.1126/science.1247490, 2014.

Sassen, K.: Evidence for Liquid-Phase Cirrus Cloud Formation from Volcanic Aerosols: Climatic Implications, Science, 257, 516-519, doi:10.1126/science.257.5069.516, 1992.

Sayer, A. M., Thomas, G. E., and Grainger, R. G.: A sea surface reflectance model for (A)ATSR, and application to aerosol retrievals, Atmos. Meas. Tech., 3, 813-838, doi:10.5194/amt-3813-2010, 2010.

Sayer, A. M., Poulsen, C. A., Arnold, C., Campmany, E., Dean, S., Ewen, G. B. L., Grainger, R. G., Lawrence, B. N., Siddans, R., Thomas, G. E., and Watts, P. D.: Global retrieval of ATSR cloud parameters and evaluation (GRAPE): dataset assessment, Atmos. Chem. Phys., 11, 3913-3936, doi:10.5194/acp-11-39132011, 2011.

Sayer, A., Smirnov, A., Hsu, N., and Holben, B.: A pure marine aerosol model, for use in remote sensing applications, J. Geophys. Res.-Atmos., 117, 813-838, doi:10.1029/2011JD016689, 2012.

Schmidt, A., Carslaw, K. S., Mann, G. W., Wilson, M., Breider, T. J., Pickering, S. J., and Thordarson, T.: The impact of the 17831784 AD Laki eruption on global aerosol formation processes and cloud condensation nuclei, Atmos. Chem. Phys., 10, 60256041, doi:10.5194/acp-10-6025-2010, 2010. 
Schmidt, A., Carslaw, K. S., Mann, G. W., Rap, A., Pringle, K. J., Spracklen, D. V., Wilson, M., and Forster, P. M.: Importance of tropospheric volcanic aerosol for indirect radiative forcing of climate, Atmos. Chem. Phys., 12, 7321-7339, doi:10.5194/acp-127321-2012, 2012.

Seinfeld, J. H. and Pandis, S. N.: Atmospheric Chemistry and Physics, 1326 pp., John Wiley, Hoboken, NJ, 1998.

Siebert, L. and Simkin, T.: Volcanoes of the World: an Illustrated Catalog of Holocene Volcanoes and their Eruptions, Smithsonian Institution, Global Volcanism Program Digital Information Series, GVP-3, www.volcano.si.edu, 2002.

Siebert, L., Simkin, T., and Kimberly, P.: Volcanoes of the World, 3rd Ed., Berkley: Univeristy of California Press, 2010.

Smirnov, A., Sayer, A. M., Holben, B. N., Hsu, N. C., Sakerin, S. M., Macke, A., Nelson, N. B., Courcoux, Y., Smyth, T. J., Croot, P., Quinn, P. K., Sciare, J., Gulev, S. K., Piketh, S., Losno, R., Kinne, S., and Radionov, V. F.: Effect of wind speed on aerosol optical depth over remote oceans, based on data from the Maritime Aerosol Network, Atmos. Meas. Tech., 5, 377-388, doi:10.5194/amt-5-377-2012, 2012.

Stevens, B. and Feingold, G.: Untangling aerosol effects on clouds and precipitation in a buffered system, Nature, 461, 607-613, doi:10.1038/nature08281, 2010.
Thomas, G. E., Poulsen, C. A., Sayer, A. M., Marsh, S. H., Dean, S. M., Carboni, E., Siddans, R., Grainger, R. G., and Lawrence, B. N.: The GRAPE aerosol retrieval algorithm, Atmos. Meas. Tech., 2, 679-701, doi:10.5194/amt-2-679-2009, 2009.

Tulet, P. and Villeneuve, N.: Large scale modeling of the transport, chemical transformation and mass budget of the sulfur emitted during the April 2007 eruption of Piton de la Fournaise, Atmos. Chem. Phys., 11, 4533-4546, doi:10.5194/acp-11-45332011, 2011.

Twohy, C. H., Coakley, J. A., and Tahnk, W. R.: Effect of changes in relative humidity on aerosol scattering near clouds, J. Geophys. Res.-Atmos., 114, 4533-4546, doi:10.1029/2008JD010991, 2009.

Twomey, S.: The influence of pollution on the shortwave albedo of clouds, J. Atmos. Sci., 34, 1149-1152, 1977.

Yuan, T., Remer, L. A., and Yu, H.: Microphysical, macrophysical and radiative signatures of volcanic aerosols in trade wind cumulus observed by the A-Train, Atmos. Chem. Phys., 11, 71197132, doi:10.5194/acp-11-7119-2011, 2011. 